\title{
Seven new giant pill-millipede species and numerous new records of the genus Zoosphaerium from Madagascar (Diplopoda, Sphaerotheriida, Arthrosphaeridae)
}

\author{
Thomas WESENER ${ }^{1, *}$ \& Christina SAGORNY ${ }^{2}$ \\ 1,2 Zoological Research Museum Alexander Koenig (ZFMK), Leibniz Institute for Animal Biodiversity, \\ Section Myriapoda, Adenauerallee 160, D-53113 Bonn, Germany. \\ ${ }^{2}$ University of Bonn, Institute of Evolutionary Biology and Ecology, D-53121 Bonn, Germany. \\ *Corresponding author: t.wesener@leibniz-zfmk.de \\ 2Email: csagorny@evolution.uni-bonn.de \\ ${ }^{1}$ urn:lsid:zoobank.org:author:86DEA7CD-988C-43EC-B9D6-C51000595B47 \\ ${ }^{2}$ urn:1sid:zoobank.org:author:9C89C1B7-897A-426E-8FD4-C747DF004C85
}

\begin{abstract}
Seven new species of the giant pill-millipede genus Zoosphaerium Pocock, 1895 are described from Madagascar: Z. nigrum sp. nov., Z. silens sp. nov., Z. ambatovaky sp. nov., Z. beanka sp. nov., $Z$. voahangy sp. nov., Z. masoala sp. nov. and Z. spinopiligerum sp. nov. All species are described based on drawings and scanning electron microscopy, while genetic barcoding of the COI gene was successful for six of the seven new species. Additional COI barcode information is provided for the first time for Z. album Wesener, 2009 and Z. libidinosum (de Saussure \& Zehntner, 1897). Zoosphaerium nigrum sp. nov. and $Z$. silens sp. nov. belong to the Z. libidinosum species-group, Z. ambatovaky sp. nov. to the $Z$. coquerelianum species-group, $Z$. beanka sp. nov., $Z$. voahangy sp. nov. and $Z$. masoala sp. nov. to the $Z$. platylabum species-group and Z. spinopiligerum sp. nov. to the $Z$. piligerum species-group. Updated identification keys are provided for each species-group. Two western dry forest species, Z. silens sp. nov. and Z. voahangy sp. nov. are recorded from two localities, while the other five species are currently only known from their type localities. Of special conservation concern might be Z. ambatovaky sp. nov. from the lowland rainforest fragment of Ambatovaky, a nowadays isolated lowland rainforest, rapidly shrinking due to slash and burn agriculture. In addition to the new species, new locality data is provided for 11 species and numerous unidentifiable species of Zoosphaerium: Z. neptunus (Butler, 1872), Z. platylabum (de Saussure \& Zehntner, 1902) and Z. piligerum (de Saussure \& Zehntner, 1897) from the central eastern montane forests, as well as Z. ambrense Wesener, 2009, Z. aureum Wesener, 2009, Z. libidinosum, Z. corystoides Wesener, 2009, Z. discolor Wesener, 2009, Z. smaragdinum Wesener, 2009, Z. villosum Wesener \& Sierwald, 2005 and Microsphaerotherium anjozorobe Wesener, 2009.
\end{abstract}

Keywords. Microendemism, Tsingy, dry forest, forest fragments, soil arthropod.

Wesener T. \& Sagorny C. 2021. Seven new giant pill-millipede species and numerous new records of the genus Zoosphaerium from Madagascar (Diplopoda, Sphaerotheriida, Arthrosphaeridae). European Journal of Taxonomy 758: 1-48. https://doi.org/10.5852/ejt.2021.758.1423 


\section{Introduction}

Madagascar, located off the eastern coast of Africa, has been isolated from other continents for more than 120 my. Its separation from India took place ca 90 my ago (Krause 2003; Ali \& Aitchison 2008). As a result of this long period of isolation, many Malagasy plant and animal groups have a high percentage of endemics, making the island an import biodiversity hotspot (Myers et al. 2000). Around $86 \%$ of the occurring invertebrate species solely live on Madagascar (Goodman \& Benstead 2005). Some of the most striking members of this endemic mega-invertebrate fauna belong to the millipedes, order Diplopoda. The so-called fire millipedes of the order Spirobolida have a conspicuous red and black coloration (Wesener et al. 2009a, 2009b, 2011a), whereas giant pill-millipedes of the order Sphaerotheriida possess stridulation organs in both sexes (Wesener \& VandenSpiegel 2009; Wesener et al. 2011b) and (only on Madagascar) can reach the size of a small orange when rolled-up (Enghoff 2003). During the last 12 years, numerous new species and genera of both groups have been described from the island (Wesener et al. 2008, 2011a, 2014; Wesener 2009, 2011; Wesener \& Enghoff 2009).

All Malagasy giant pill-millipedes belong to the family Arthrosphaeridae, which comprises four genera. Three genera are strictly endemic to Madagascar, while a fourth genus is found in southern India and Sri Lanka (Wesener \& VandenSpiegel 2009; Wesener et al. 2010a). This peculiar biogeographic pattern represents the shared connection between Madagascar and India until 90 my ago. Species of the geographically closest family, Sphaerotheriidae, are found in South Africa. The strictly endemic Malagasy giant pill-millipedes belong to the genera Sphaeromimus de Saussure \& Zehntner, 1902, Microsphaerotherium Wesener \& VandenSpiegel, 2007 and Zoosphaerium Pocock, 1895. In the genus Zoosphaerium, comprising the vast majority of species, 42 new species have been described since 2005 . Many of these species are endemic to very restricted geographical areas and are therefore listed as critically endangered on the IUCN Red List (e.g., Rudolf \& Wesener 2017a, 2017b).

In an effort to understand Madagascar's role as a major biodiversity hotspot, two general inventory programs have recently been undertaken: one organized by the Field Museum, Chicago and headed by Steve Goodman and his team, and a second organized by the California Academy of Sciences, headed by Brian Fisher and his team. Both programs yielded numerous samples of Malagasy giant pill-millipedes. In total, these samples contained specimens of 11 already described species as well as seven new species which are described here.

\section{Material \& methods}

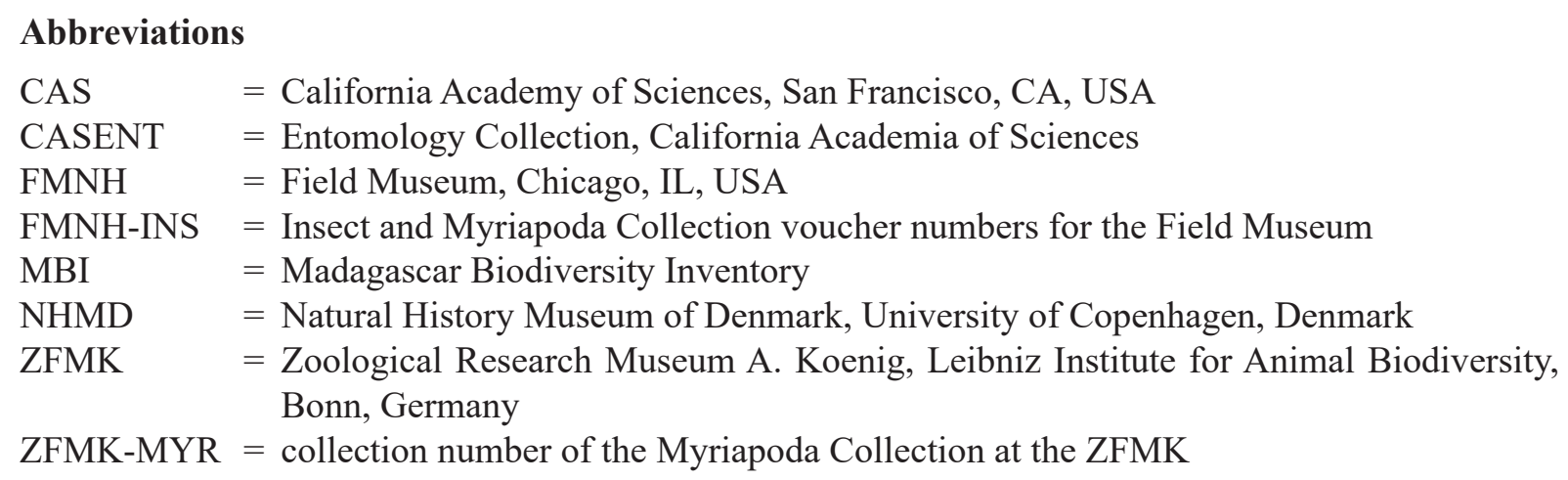

\section{Dissection and illustrations}

Structures were dissected and drawn using a camera lucida mounted on an Olympus SZX12 stereo microscope. Pencil drawings were transferred to ink using Pigma Micron pens with widths 005 and 04 and later edited in Adobe Photoshop CS2. The naming of morphological structures follows the terms established in previous papers (Wesener \& Sierwald 2005a; Wesener 2009). 


\section{Photography and scanning electron microscopy}

Habitus photographs were taken at multiple focal planes with a DUN (Palmyra, Virginia) BK-Plus imaging system based at the ZFMK. Images were stacked using the software Auto-Montage (Syncroscopy). For scanning electron microscopy (SEM), the endotergum was dissected. The samples were cleaned and dehydrated via an ethanol series $(2 \times$ at $96 \%, 3 \times$ at $100 \%)$ before being mounted on aluminum stubs. The samples were coated with gold for 240 seconds in a sputter coater. SEM images were taken using a Supra VR 300VP (Carl Zeiss AG) scanning electron microscope utilizing the Software SmartSEM ver. 5.00, based at the ZFMK. After the study, dry coated SEM material was removed from stubs and returned to alcohol. All images were later edited using Adobe Photoshop CS2 and assembled into plates in Adobe Illustrator CS2.

\section{DNA extraction and molecular barcoding}

In order to match males to females, investigate the intraspecific and interspecific genetic distances of the species described here, as well as elucidate phylogenetic relationships a molecular genetic barcoding study (Hebert et al. 2003) was conducted. Genomic DNA was extracted from the muscle tissue of the legs of 12 specimens of Zoosphaerium (see Table 1). In order to barcode the specimens, the cytochrome $c$ oxidase subunit I was amplified. Information on DNA extraction, PCR and sequencing procedures can be obtained from a previous study (Sagorny \& Wesener 2017). BLAST searches (Altschul et al. 1997) were performed to confirm sequence identities. Sequences were concatenated by hand or utilizing the software Seqman (DNASTAR Inc.). The entire dataset was translated into amino acids to rule out the accidental amplification of pseudogenes. Fifteeen additional COI sequences representing seven different species of Zoosphaerium described in previous studies (Wesener et al. 2010a; Sagorny \& Wesener 2017; Wesener \& Anilkumar 2020) were downloaded from GenBank. Moreover, two sequences of the closely related Malagasy genus Sphaeromimus (Wesener \& Sierwald 2005b; Wesener et al. 2014; Moritz \& Wesener 2017) as a near outgroup and one sequence of the basal (Wesener \& VandenSpiegel 2009; Wesener 2014) Sphaerotheriida family Procyliosomatidae as a far outgroup were added to the dataset.

All sequences were aligned in Bioedit (Hall 1999). The final dataset included 30 sequences from 22 morphospecies with 674 positions (12 newly sequenced, 18 from Genbank). Sequences of newly sequenced specimens were uploaded to Genbank and their accession codes (MW633250-MW633261) are provided here (Table 1).

A phylogenetic tree was reconstructed in the IQ-TREE web server (Trifinopoulos et al. 2016) using a maximum likelihood (ML) as the optimality criterion. General Time Reversible (GTR) (Tavaré 1986) and a gamma distribution with a proportion of invariant sites was selected as the best fitting model by IQ-TREE. Branch support was estimated based on an ultrafast bootstrap analysis using 1000 bootstrap replicates. The resulting tree (Fig. 1) was edited in Adobe Illustrator CS2.

Using the p-distances approach, a pairwise distance analysis was conducted in MEGA6 (Tamura et al. 2013). A table listing all calculated distances is provided (Table 2).

\section{Results}

\section{Barcoding analysis}

Intraspecific distances are between 0 and $2.5 \%$, if female specimens whose identity is unknown are excluded (Table 2). In contrast to this, interspecific distances between the 15 identified species of the genus Zoosphaerium vary between 9.1 and $20 \%$. The lowest interspecific distance (9.1\%) is observed between Z. minutus Sagorny \& Wesener, 2017 and Z. mangabe Wesener, 2017, but a similarly low p-distance $(9.8 \%)$ is present between $Z$. ambatovaky sp. nov. and Z. villosum. All other interspecific distances are above $10 \%$. 
Table 1. Material examined for molecular data. CAS = California Academy of Sciences, San Francisco; FMNH $=$ Field Museum of Natural History, Chicago; MZUF = Museum "La Specola", Florence, Italy; ZFMK = Zoological Research Museum Alexander Koenig, Bonn, Germany. Specimens marked by an asterisk (12) were newly sequenced for this study. $M=$ Madagascar.

\begin{tabular}{|c|c|c|c|}
\hline Species & Voucher number & Genbank \# & Locality \\
\hline Procyliosoma leae (Silvestri, 1917) & QVMAG 23:45801 & FJ409910.1 & Australia, Tasmania \\
\hline Sphaeromimus musicus (de Saussure \& Zehntner, 1897) & ZFMK MYR 2273 & KJ713244.1 & M, Tsimelahy \\
\hline Sphaeromimus musicus (de Saussure \& Zehntner, 1897) & ZFMK MYR 2276 & KJ713245.1 & M, Tsimelahy \\
\hline Zoosphaerium album Wesener, 2009 * & ZFMK MYR 7202 & MW633250 & M, Makay \\
\hline Zoosphaerium alluaudi (de Saussure \& Zehntner, 1897) & FMNH-INS 56000 & FJ409926.1 & M, Petriky \\
\hline Zoosphaerium alluaudi (de Saussure \& Zehntner, 1897) & FMNH-INS & FJ409927.1 & M, Petit Lavasoa \\
\hline Zoosphaerium ambatovaky sp. nov. (holotype) * & CASENT 9068294/1 & MW633257 & M, Ambatovaky \\
\hline Zoosphaerium bartolozzii Wesener \& Anilkumar, 2020 & MZUF & MN783351 & M, Ambalamanakana \\
\hline Zoosphaerium beanka sp. nov. (holotype) * & FMNH-INS 3119897 & MW633258 & M, Beanka \\
\hline Zoosphaerium bemanevika Sagorny \& Wesener, 2017 & FMNH-INS 2858678 & KY399019.1 & M, Bemanevika, Matsaborimena \\
\hline Zoosphaerium bemanevika Sagorny \& Wesener, 2017 & FMNH-INS 3196510 & KY399020.1 & M, Bemanevika, Amberivery \\
\hline Zoosphaerium bemanevika Sagorny \& Wesener, 2017 & FMNH-INS 2858686C & KY399021.1 & M, Bemanevika, Amberivery \\
\hline $\begin{array}{c}\text { Zoosphaerium libidinosum } \\
\text { (de Saussure \& Zehntner, 1897) * }\end{array}$ & $\begin{array}{l}\text { ZFMK MYR35/ } \\
\text { Mangatsiaka }\end{array}$ & MW633251 & M, Mangatsiaka \\
\hline Zoosphaerium mangabe Wesener, 2020 & FMNH-INS 2858681B & KY399026.1 & M, Marojejy \\
\hline Zoosphaerium minutus Sagorny \& Wesener, 2017 & FMNH-INS 2858676 & KY399022.1 & M, Bemanevika, Matsaborimena \\
\hline Zoosphaerium minutus Sagorny \& Wesener, 2017 & FMNH-INS 2858686A & KY399023.1 & M, Bemanevika, Amberivery \\
\hline Zoosphaerium nigrum sp. nov. (holotype) * & CASENT9068289 & MW633254 & M, Midongy \\
\hline Zoosphaerium neptunus (Butler, 1872) & FMNH-INS 56005 & FJ409929.1 & M, Perinet \\
\hline Zoosphaerium silens sp. nov. (holotype) * & FMNH-INS 3119887 & MW633252 & M, Kirindy-Mite \\
\hline Zoosphaerium silens sp. nov. * & FMNH-INS 3119875 & MW633253 & M, Andranomena \\
\hline Zoosphaerium spinopiligerum sp. nov. (holotype) ${ }^{*}$ & FMNH-INS 3119885 & MW633255 & M, Midongy-Befotaka \\
\hline Zoosphaerium cf. spinopiligerum sp. nov. () * & $\begin{array}{l}\text { FMNH-INS 3119888/ } \\
\text { ZFMK }\end{array}$ & MW633256 & M, Midongy-Befotaka \\
\hline Zoosphaerium villosum (Wesener \& Sierwald, 2005) & ZFMK-MYR 00330 & KY399028.1 & M, Ambodivohangy \\
\hline Zoosphaerium voahangy sp. nov. (holotype) * & FMNH-INS 3119921 & MW633260 & M, Analava \\
\hline Zoosphaerium voahangy sp. nov. (paratype) * & $\begin{array}{l}\text { FMNH-INS 3119919/ } \\
\text { (ZFMK) }\end{array}$ & MW633261 & M, Ambinda \\
\hline Zoosphaerium sp. Brown & FMNH-INS 56072 & FJ409931.1 & M, Ivorona \\
\hline Zoosphaerium sp. Green & FMNH-INS 3119870 & KY399027.1 & M, Brickaville \\
\hline Zoosphaerium sp. Ma & FMNH-INS 3195649 & KY399024.1 & M, Masoala, Ambohitsito \\
\hline Zoosphaerium sp. Ma & FMNH-INS 3195650 & KY399025.1 & M, Masoala, Sarahandrano \\
\hline Zoosphaerium sp. Anjiamangirina * & FMNH-INS 3119906 & MW633259 & M, Anjiamangirina \\
\hline
\end{tabular}

The maximum likelihood analysis of the COI barcoding gene does not support the monophyly of Zoosphaerium (Fig. 1), as Sphaeromimus musicus is nested within the Zoosphaerium clade. All individual species of Zoosphaerium comprising more than one sequence are well-supported ( $>99 \%)$, but interspecific relationships mostly lack sufficient statistical support (Fig. 1). One well-supported clade comprises Zoosphaerium silens sp. nov., Z. album and Z. libidinosum (95\%). Furthermore, the clade comprising Zoosphaerium ambatovaky sp. nov., Z. bemanevika, and Z. villosum as well as two unidentified species of Zoosphaerium from Brickaville and Masoala, respectively, receives good support (98\%). A third, well-supported sister group relation is visible between an unnamed female Zoosphaerium from Anjiamangirina and Zoosphaerium voahangy sp. nov. 
WESENER T. \& SAGORNY C., Seven new giant pill-millipedes from Madagascar

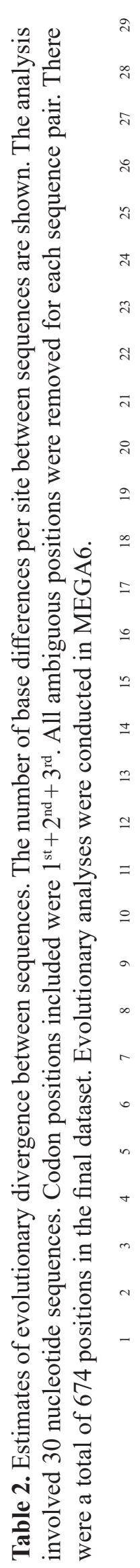

i

.

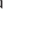

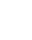

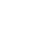

ง

(1)

i

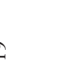

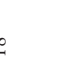




\section{Taxonomy}

Class Diplopoda de Blainville in Gervais, 1844

Order Sphaerotheriida Brandt, 1833

Family Arthrosphaeridae Jeekel, 1974

Genus Zoosphaerium Pocock, 1895

Zoosphaerium Pocock, 1895: 410.

Globotherium Brolemann, 1922: 230 (formal synonymization in Wesener \& Wägele 2008: 9).

Heligmasoma Chamberlin, 1921: 58 (formal synonymization in Wesener \& Wägele 2008: 9).

See Wesener (2016) for a summary; five additional species have been described since then (Sagorny \& Wesener 2017; Wesener \& Anilkumar 2020).

\section{Type species}

Sphaerotherium neptunus Butler, 1872.

\section{Other species included}

66 and 11 nomina dubia (including the species described below).

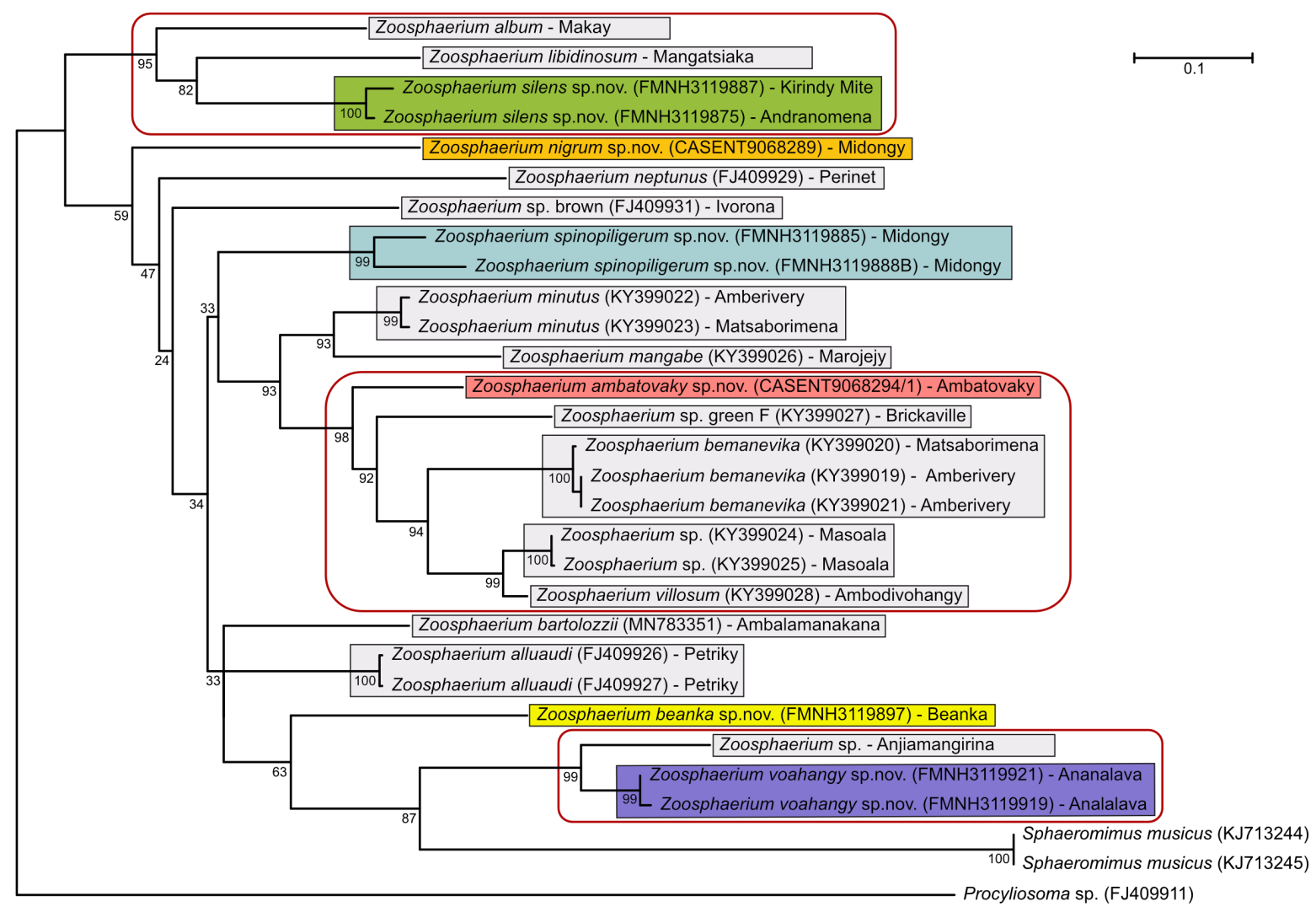

Fig. 1. Maximum likelihood tree inferred from the COI dataset with 1000 bootstrap pseudoreplicates implementing the GTR $+\mathrm{I}+\mathrm{G}$ model. Colors representing newly described species of Zoosphaerium: orange $=Z$. nigrum sp. nov.; green $=Z$. silens $\mathrm{sp}$. nov.; $\mathrm{red}=Z$. ambatovaky sp. nov.; yellow $=Z$. beanka sp. nov.; purple $=Z$. voahangy sp. nov.; blue $=Z$. masoala sp. nov. Round-cornered rectangles indicate well-supported sister group relationships. 


\section{Distribution}

Endemic to Madagascar.

\section{Remarks}

The diverse genus Zoosphaerium has been divided into six species-groups (Wesener \& Wägele 2008; Wesener 2009). Six additional species are currently not assignable to any group (Sagorny \& Wesener 2017). Four species are only known from females and an additional 11 species are nomina dubia. A key to the species-groups has been published elsewhere (Wesener 2009).

\section{Zoosphaerium libidinosum species-group}

\section{Remarks}

Species can be identified as members of the Z. libidinosum species-group based on morphological characters of the posterior telopods, in which the third telopoditomere carries more than 15 large crenulated teeth as well as two large membranous lobes (Wesener \& Wägele 2008). The species-group now contains 16 described species distributed in all types of forests all over Madagascar, including the arid spiny bush (Wesener 2009).

\section{Key to species of the Zoosphaerium libidinosum species-group}

1. Anal shield without locking carinae (in small, immature individuals sometimes traces of carinae

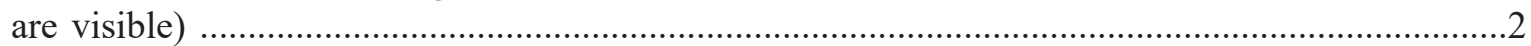

- Anal shield with two obvious locking carinae ...............................................................

2. Operculum of vulva at least weakly notched apically. Fifth antennomere with field of sensilla basiconica apically .3

- Operculum of vulva well-rounded apically. No sensilla basiconica present on fifth antennomere

3. Tergites dark green, in alcohol almost blackish, posterior margin light brown to yellow. Tarsus of walking legs broad, only 3.0 times as long as wide. Third podomere of anterior telopods with four large, sclerotized teeth. Endotergal marginal bristles strongly extending beyond tergite ........

Z. haackeri Wesener, 2009

- Tergites almost white, with light, shiny-green field dorso-laterally on each side. Tarsus of walking legs of usual size, 3.8 times as long as wide. Third podomere of anterior telopods with single large, sclerotized tooth. Endotergal marginal bristles slightly extending beyond tergite

Z. album Wesener, 2009

4. Anterior telopod second podomere process slightly extending beyond third podomere. Third podomere laterally with plateau and mesally with a sharp, prominent process. Tergites light green with distinct, light brown posterior margin. Male harp with two weakly-developed stridulation ribs

Z. discolor Wesener, 2009

- Anterior telopod second podomere process shorter than third podomere. Third podomere of anterior telopods only laterally with plateau

5. Tergites dark, almost blackish green, posteriorly with distinct and wide light brown margin. Anal shield covered with numerous short hairs. Endotergum with a single row of marginal bristles, slightly extending beyond tergite Z. mitoho Wesener, 2009

- Tergites with dark green, light green pattern, posteriorly with distinct, thin light brown margin. Anal shield glabrous. Endotergum with two or more rows of marginal bristles, clearly extending beyond apical margin 
6. Endotergum with $\geq 3$ rows of marginal bristles, strongly extending beyond tergite. Third podomere of anterior telopods laterally with a triangular projection. Tarsi of walking legs $>3.7$ times as long as wide. Male harp with two strongly developed stridulation ribs

Z. libidinosum (de Saussure \& Zehntner, 1897)

- Endotergum with two rows of marginal bristles, strongly extending beyond tergite. Third podomere of anterior telopods laterally without triangular projection. Tarsi of walking legs 3.5 times as long as wide. Male harp with two weakly developed stridulation ribs Z. silens sp. nov.

7. Second and third podomeres of posterior telopods covered with numerous minute hairs. Antennae with four apical cones; tergites glossy, glabrous

- Second and third podomeres of posterior telopods glabrous or covered with long setae ............10

8. Tergites black. Anterior telopod with one stridulation rib Z. nigrum sp. nov.

- Tergites jade-like green. Anterior telopod at least apically with 2 stridulation ribs

9. Tergites glossy, completely jade-like green. Male harp with two basally fused stridulation ribs. Third podomere of anterior telopods mesally with sharp, prominent process. Endotergum with one row of rounded cuticular impressions. Fixed finger of posterior telopod basally without membranous lobe Z. anomalum (de Saussure \& Zehntner, 1902)

- Tergites glossy, jade-like green, with shiny dark green pattern. Male harp with two fully separate stridulation ribs. Third podomere of anterior telopods without process. Endotergum without cuticular impressions. Fixed finger of posterior telopod with basal membranous lobe

Z. pulchellum Wesener, 2009

10. Posterior end of anal shield in both sexes excavated ...........................................................11

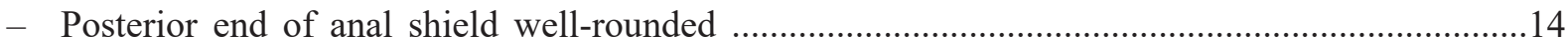

11. Tergites glossy, green. Male harp with two weakly-developed stridulation ribs. Third podomere of anterior telopods with a single large sclerotized tooth .............. en endemicum Wesener, 2009

- Tergites matte, brownish. Male harp with two well-developed stridulation ribs ........................12

12. Locking carinae on anal shield of similar length. Third podomere of posterior telopods with ca 28 large sclerotized teeth. Antenna with more than 40 apical cones

Z. xerophilum Wesener, 2009

- Posterior locking carina at least two times as long as anterior carina. Third podomere of posterior telopods with less than 25 large sclerotized teeth. Antenna with less than 30 apical cones ......

13. Posterior locking carina of anal shield more than three times as long as anterior carina

Z. arborealis Wesener \& Sierwald, 2005

- Posterior locking carina ca twice as long as anterior one .....Z. lambertoni (Brolemann, 1922)

14. Anal shield glabrous, golden. Tergites with unique pitch-black/reddish-brown pattern. Third podomere of anterior telopods without large sclerotized teeth. First antennomere without sensilla basiconica. Sclerotized teeth present on antennomeres 1-4. Endotergal marginal bristles not extending beyond tergite margin

Z. aureum Wesener, 2009

- Anal shield covered with few, minute hairs of dirty brownish color. Tergites with light brown, blackish coloration pattern. Third podomere of anterior telopods laterally with at least a single large sclerotized tooth. First antennomere with sensilla basiconica. Sclerotized teeth present on antennomeres 1-5. Endotergal marginal bristles slightly extending beyond tergite margin .........15 
15. Legs short, femur 1.45 times as long as wide, tarsus 3.2 times as long as wide. Third pair of legs without apical spine. Third podomere of posterior telopods with ca 18 large sclerotized teeth. Endotergum with two rows of marginal bristles. Posterior locking carina 4 times as long as anterior carina. Antenna with 25 or fewer apical cones .......... priapus (de Saussure \& Zehntner, 1897)

- Legs of usual size, femur 1.9 times as long as wide, tarsus 4.2 times as long as wide. Third pair of legs with apical spine. Third podomere of posterior telopods with ca 22 large sclerotized teeth. Endotergum with three rows of marginal bristles. Locking carinae of equal size. Antenna with 35-86 apical cones Z. pseudopriapus Wesener, 2009

\author{
Zoosphaerium nigrum sp. nov. \\ urn:1sid:zoobank.org:act:4F170F43-C7A9-44A4-A004-47FD58FDBA2F
}

Figs $2 \mathrm{~A}, 3-4,5 \mathrm{~A}$

\title{
Diagnosis
}

Posterior telopods (Fig. 4H-I) identify this species as a member of the Z. libidinosum species-group. Within this group, Zoosphaerium nigrum sp. nov. shares a number of characters with only Z. anomalum (de Saussure \& Zehntner, 1902) and Z. pulchellum Wesener, 2009. These include the presence of two locking carinae, four apical cones on each antenna, and shiny, glossy tergites. Moreover, the second and third podomeres of the posterior telopods are covered with numerous minute hairs. Zoosphaerium nigrum sp. nov. differs from these two species in the black coloration (jade-like green in the others), the presence of only a single weak stridulation rib on the anterior telopod and differently shaped podomeres.

\section{Etymology}

'Nigrum', adjective, after the dark colour of the species.

\section{Material examined}

\section{Holotype}

MADAGASCAR - Fianarantosa - Ō; Parc National Befotaka-Midongy, Papango, $28.5 \mathrm{~km} \mathrm{~S}$ of

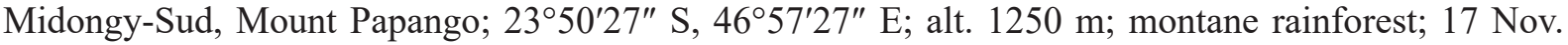
2006; B.L. Fisher et al. leg.; coll. no. BLF14945; CASENT 9068289.

\section{Description}

\section{Male}

BoDY LENGTH. Holotype male: length ca $28 \mathrm{~mm}$, width of thoracic shield $13.1 \mathrm{~mm}$, of tergite $713.5 \mathrm{~mm}$ (widest), height of thoracic shield $7.1 \mathrm{~mm}$, of tergite $77.4 \mathrm{~mm}$ (highest).

COLORATION. Some discoloration may have occurred because of preservation in ethanol. Tergites, head, anal shield and appendages dark green to black (Fig. 2A). Posterior margin of tergites with a thin brown margin.

HeAD. Wide and short. Eyes with $>120$ ommatidia. Aberrant ocellus located in antennal groove. Antennae short, with cylindrical joints, reaching posteriorly to leg pair 3. Length of antennomeres $1=2=3=4=5<6$. A shallow groove present on antennomere 1 . Male apical disc with four apical sensory cones. Organ of Tömösváry located in antennal groove.

GNATHOCHILARIUM AND MANDIBLE. Not dissected. 

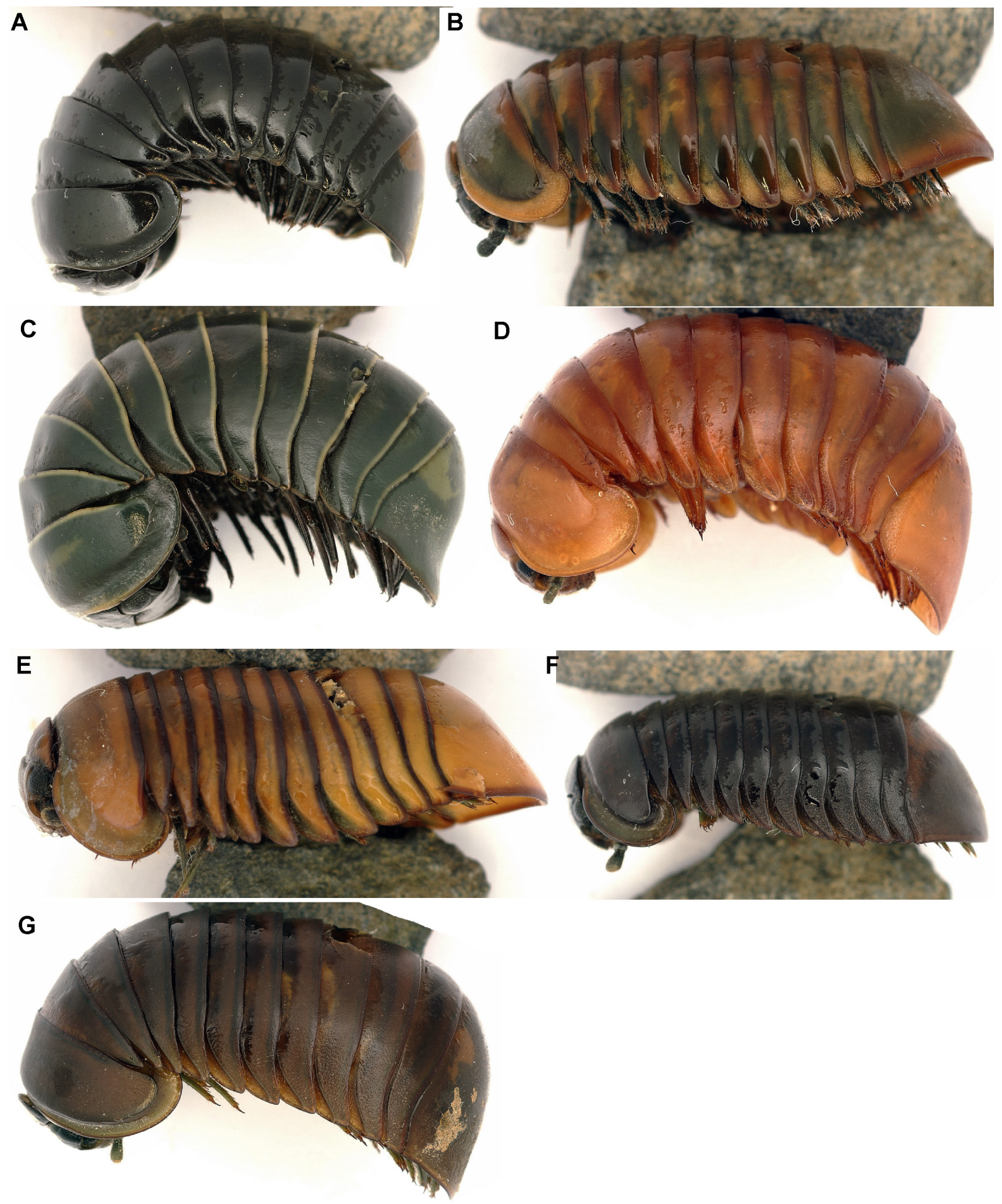

Fig. 2. Habitus photographs of the seven new species of Zoosphaerium, lateral view. A. Zoosphaerium nigrum sp. nov., holotype (CASENT 9068289). B. Z. silens sp. nov., holotype (FMNH-INS 3119887). C. Z. ambatovaky sp. nov., holotype (CASENT 9068294/1). D. Z. beanka sp. nov., holotype (FMNH-INS 3119897). E. Z. voahangy sp. nov., holotype (FMNH-INS 3119921). F. Z. masoala sp. nov., holotype (FMNH-INS 3195651). G. Z. spinopiligerum sp. nov., holotype (FMNH-INS 3119885). Not to scale. 


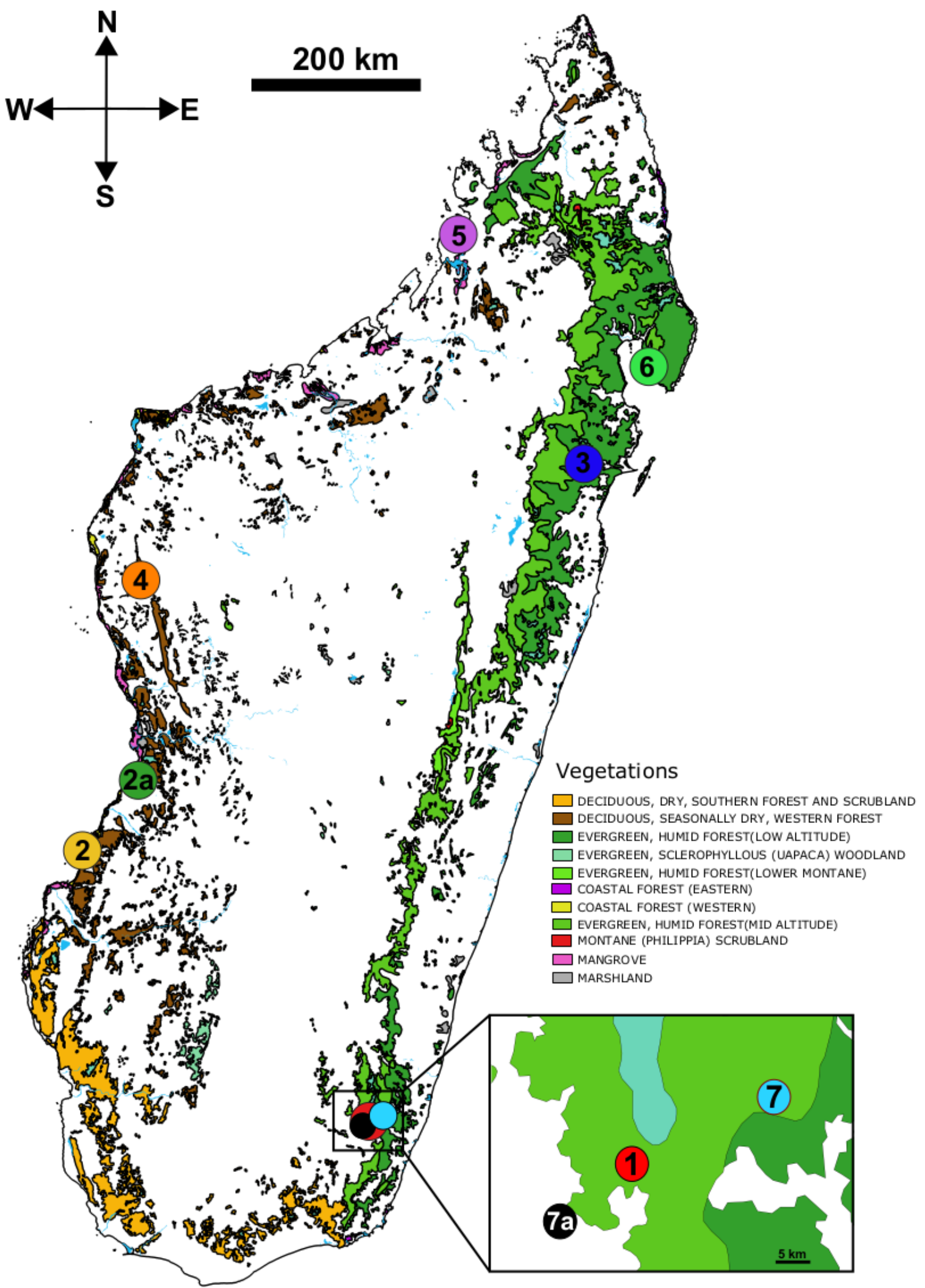

Fig. 3. Distribution map of the newly described species of Zoosphaerium. Vegetation color marks modified from Moat \& Smith 2007. $1=Z$. nigrum sp. nov.; $2=Z$. silens sp. nov.; $3=Z$. ambatovaky sp. nov.; $4=Z$. beanka sp. nov.; $5=Z$. voahangy sp. nov.; $6=Z$. masoala sp. nov.; $7=Z$. spinopiligerum sp. nov. Numbers followed by 'a' mark additional, non-type localities. 

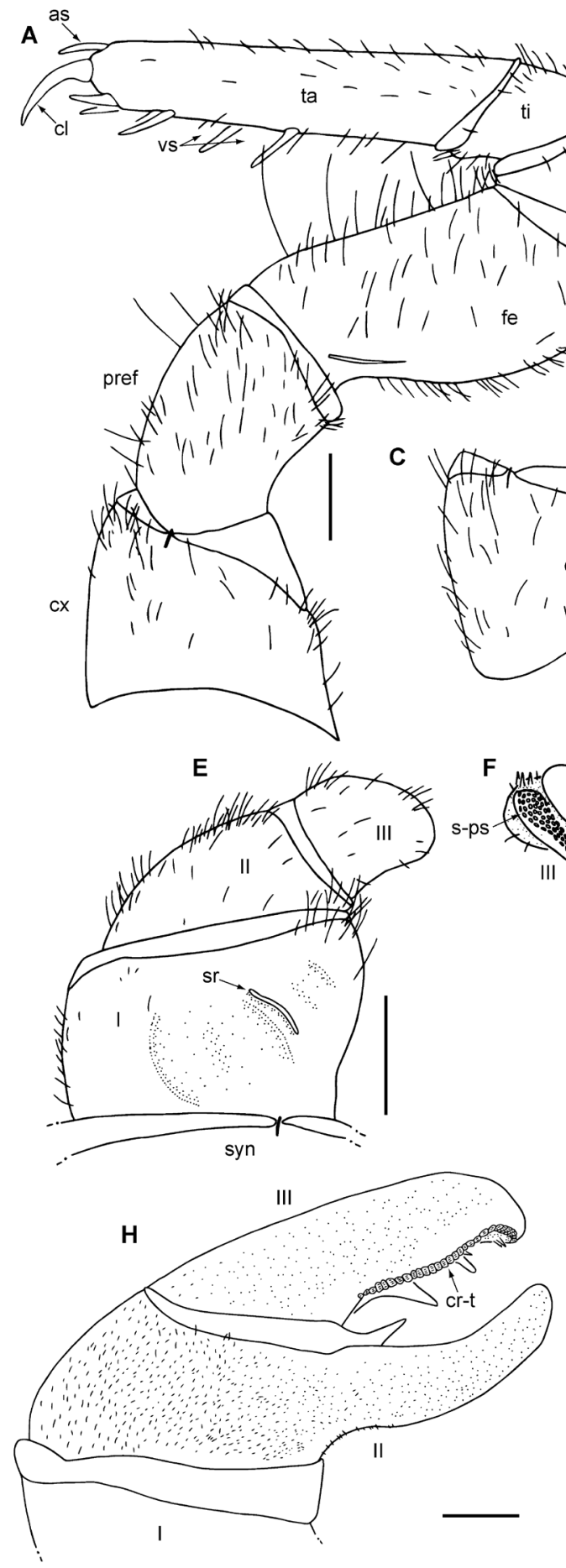

B

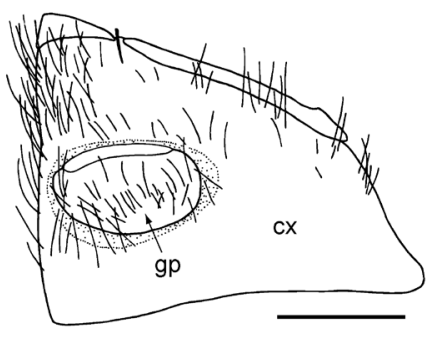

D
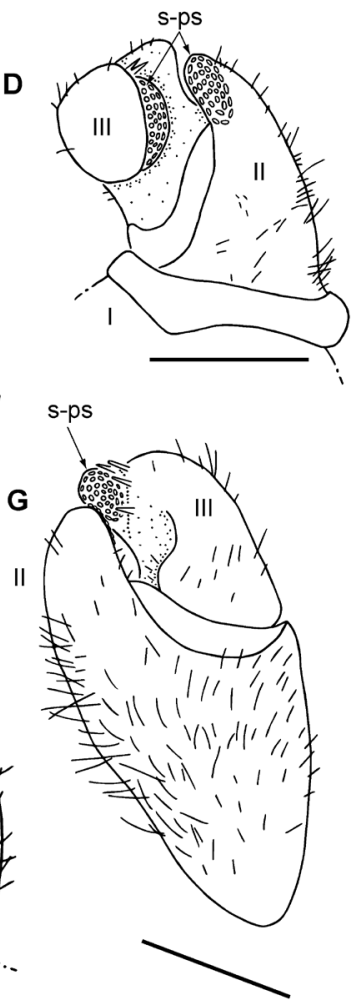
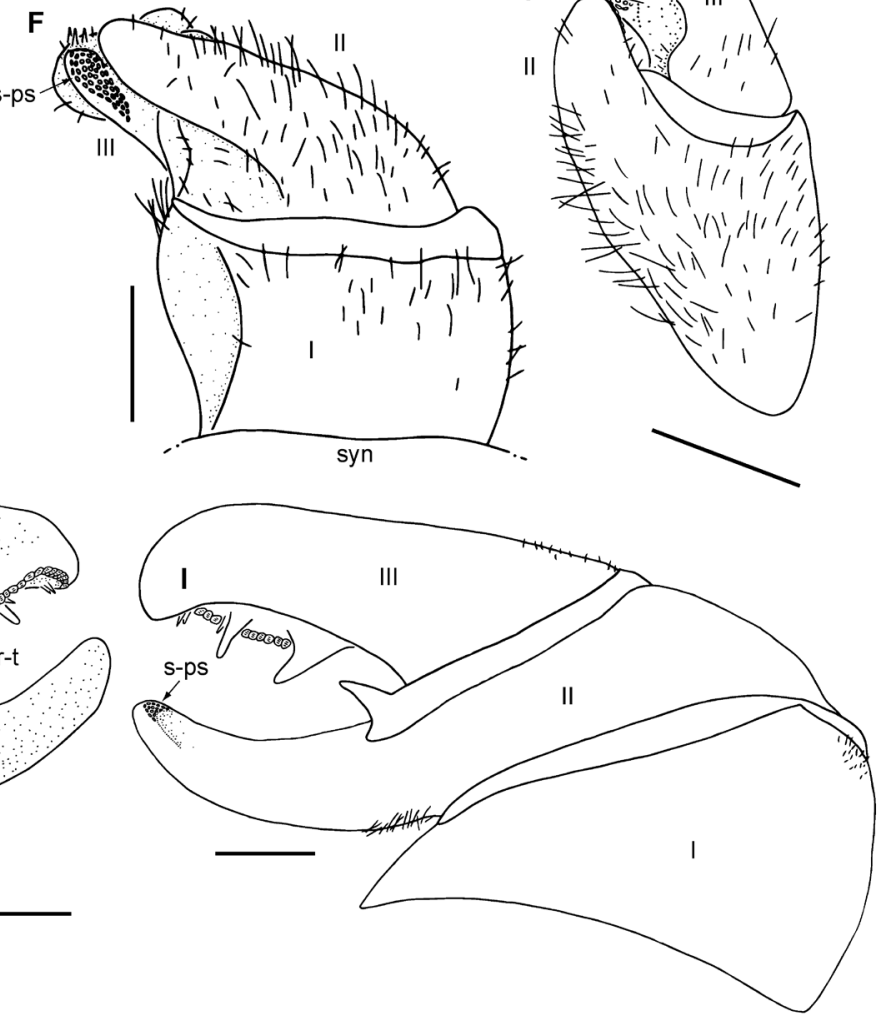

Fig. 4. Zoosphaerium nigrum sp. nov., holotype (CASENT 9068289). A. Left leg 9, posterior view. B. Left coxa 2 with gonopore, posterior view. C. Left coxa 1 with stigmatic plate, posterior view. D. Left anterior gonopod, mesal view. E. Left anterior gonopod, anterior view. F. Left anterior gonopod, posterior view. G. Left anterior gonopod, lateral view. H. Right posterior telopod, posterior view. I. Right posterior telopod, anterior view. Abbreviations: as = apical spine; $\mathrm{cl}=\mathrm{claw}$; $\mathrm{cr}-\mathrm{t}=$ crenulated teeth; $\mathrm{cx}=$ coxa; $\mathrm{fe}=$ femur; $\mathrm{gp}=$ gonopore; pof = postfemur; pref = prefemur; s-ps = sclerotized spots; $\mathrm{sr}=$ stridulation $\mathrm{rib} ; \mathrm{st}=$ stigmatic plate; $\mathrm{syn}=$ syncoxite $; \mathrm{ta}=$ tarsus; $\mathrm{ti}=$ tibia; $\mathrm{vs}=$ ventral spines. Roman numerals indicate telopoditomeres. Scale bars $=1 \mathrm{~mm}$. 

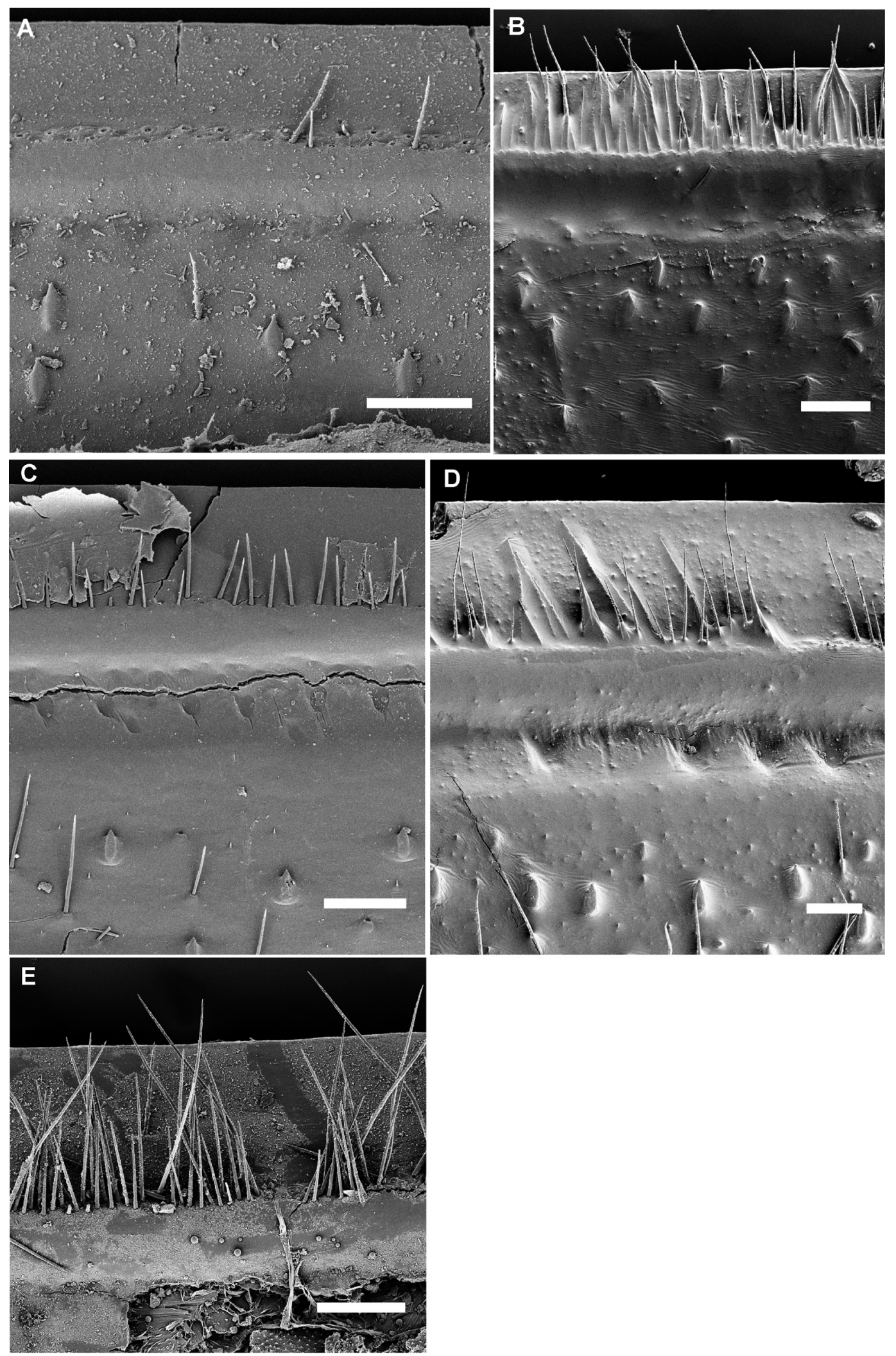

Fig. 5. Scanning electron micrographs of the endoterga of midbody rings. A. Zoosphaerium nigrum sp. nov., holotype (CASENT 9068289). B. Z. silens sp. nov., holotype (FMNH-INS 3119887). C. Z. ambatovaky sp. nov., holotype (CASENT 9068294/1). D. Z. beanka sp. nov., holotype (FMNHINS 3119897). E. Z. voahangy sp. nov., holotype (FMNH-INS 3119921). Scale bars $=100 \mu \mathrm{m}$. 
Stigmatic PLATES. First stigmatic plate triangular, apex well rounded, nearly as wide as at base. Mesal margin straight, not curved towards coxa. Hair most abundant on apical margin, very few hairs on basal and lateral margins (Fig. 4C).

PLEURITES. First pleurite laterally modified and extending backwards with a broad, apically rounded process. Other pleurites well-rounded.

Collum. Glabrous with very sparse setae around margins, mostly located at corners on either side of head.

THORACIC SHIELD. Smooth and glabrous, without protuberances.

TERGites. Surface glabrous and shiny, lacking small pits. Tips of paratergites of midbody tergites projecting posteriorly.

ENDOTERGUM. Inner section with numerous short triangular spines and very few longer setae. Middle area above spines with single row of sparse, circular cuticular impressions slightly varying in size. Apically a single row of short marginal bristles, protruding to $2 / 3$ distance to tergite margin. Bristles with numerous small spines (Fig. 5A).

ANAL SHIELD. Large and slightly bell-shaped. Several tiny setae present in posterior part. Underside with two black locking carinae, posterior one 2 times as long as anterior one, both located close to anal shield margin.

LEGS. Leg 1 with 5 ventral spines, leg 2 with 3, leg 3 with 3-5. First two leg pairs without an apical spine, spine present on leg 3. Leg pairs 4-21 with 5-7 ventral spines and an apical spine. On leg 9, femur 1.8 and tarsus 4.6 times as long as wide. All podomeres with setae (Fig. 4A).

\section{Male sexual characters}

GONOPORE. Covered with a single undivided, rounded membranous plate (Fig. 4B).

ANTERIOR TELOPODS. Harp with a single weak stridulation rib (Fig. 4E). First podomere with only a few setae, restricted to apical parts of lateral margins, 1.5 times wider than long. Process of second podomere as long as $2 / 3$ of third podomere, not visible in anterior view, with apical mound of a few sclerotized spots juxtaposed to third podomere. Third podomere without sclerotized teeth, but with a conspicuous process carrying sclerotized spots (Fig. 4F-G); base of process with four spines (Fig. 4G). Second and third podomeres sparsely setose.

POSTERIOR TELOPODS. Movable finger weakly curved; hollowed-out inner margin with two non-sclerotized lobes and ca three smaller sclerotized spines, posterior aspect with ca 29 crenulated teeth. Fixed finger thinner than movable finger, with slightly curved tip; basally with single membranous lobe, on inner margin covered with numerous sclerotized spots. Second and third podomeres without any long hair, but on both sides densely covered with very small pits, one very small seta standing in each pit. First podomere without those pits but with some isolated, standard longer hairs.

\section{Female}

Unknown.

\section{Distribution and ecology}

Zoosphaerium nigrum sp. nov. is currently known only from the montane rainforests of MidongyBefotaka (Fig. 3) where it coexists with another species of the genus, Z. spinopiligerum sp. nov. (see below), as well as with a species of the genus Sphaeromimus (Moritz \& Wesener 2017). 


\section{Zoosphaerium silens sp. nov. urn:1sid:zoobank.org:act:2FA555CB-B805-401A-8730-6DFB6525C585}

Figs $2 \mathrm{~B}, 3,5 \mathrm{~B}, 6$

\section{Diagnosis}

The posterior telopods (Fig. 6H-I) identify Z. silens sp. nov. as a member of the Z. libidinosum speciesgroup. Zoosphaerium silens sp. nov. shares the absence of locking carinae with a number of spiny forest species. It differs from all other species except Z. libidinosum in the color of the tergites, the glabrous anal shield and the presence of at least two rows of very long endotergal bristles. Zoosphaerium silens sp. nov. differs from $Z$. libidinosum in the wider tarsus (3.5 versus 3.8 times as long as wide), the presence of only two rows of endotergal bristles (three rows in Z. libidinosum) and the absence of a lateral triangular projection on the third podomere of the anterior telopods (present in Z. libidinosum).

Z. silens sp. nov. differs by more than $14 \%$ uncorrected p-distance in the COI gene from Z. album and Z. libidinosum.

\section{Etymology}

'Silens' (= 'quiet'), noun in apposition, after the reduced stridulation ribs in the male.

\section{Material examined}

\section{Holotype}

MADAGASCAR - Toliara - ơ; Parc National de Kirindy Mite, $25.6 \mathrm{~km}$ SW of Belo sur Mer; $20^{\circ} 56.6^{\prime} \mathrm{S}, 43^{\circ} 52.3^{\prime} \mathrm{E}$; alt. $10 \mathrm{~m}$; dry deciduous forest; 9 Mar. 2007; V. Soarimalala leg.; coll. no. VS1348; FMNH-INS 3119887.

\section{Paratype}

MADAGASCAR - Toliara • + ; same collection data as for holotype; FMNH-INS 3119887.

\section{Other material}

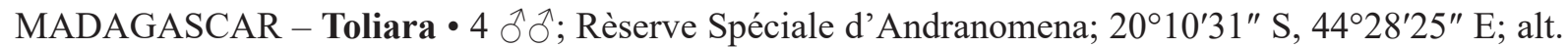
18 m; dry deciduous forest; 12 Mar. 2010; V. Soarimalala leg.; coll. no. VS-1815; FMNH-INS 3119875 - 1 ô; same collection data as for preceding; ZFMK MYR11137.

\section{Description}

Body LENGTH. Largest female (paratype): length ca $27.2 \mathrm{~mm}$, width of thoracic shield $14.3 \mathrm{~mm}$, of tergite $814.8 \mathrm{~mm}$ (widest), height of thoracic shield $8.2 \mathrm{~mm}$, of tergite $810.1 \mathrm{~mm}$ (highest).

COLORATION. Some discoloration may have occurred because of preservation in ethanol. Tergites dorsally orange to brown, especially at posterior margin, laterally green except for paratergite depressions which are yellow. Anal shield light brown to yellowish dorsally as well as posteriorly, laterally green. Thoracic shield green, but grooves and margins yellow-brownish (Fig. 2B). Head and antennae green, legs basally light brown, apically green.

HEAD. Wide and short. Eyes with $>75$ ommatidia. Aberrant ocellus located in antennal groove. Antennae short, with cylindrical joints, protruding posteriorly to leg pair 3. Length of antennomeres $1=2=3=4=5<6$. A shallow groove present on antennomere 1 . Male apical disc with 11 or 12 apical sensory cones. Organ of Tömösváry located in antennal groove.

GNATHOCHILARIUM AND MANDIBLE. Not dissected. 


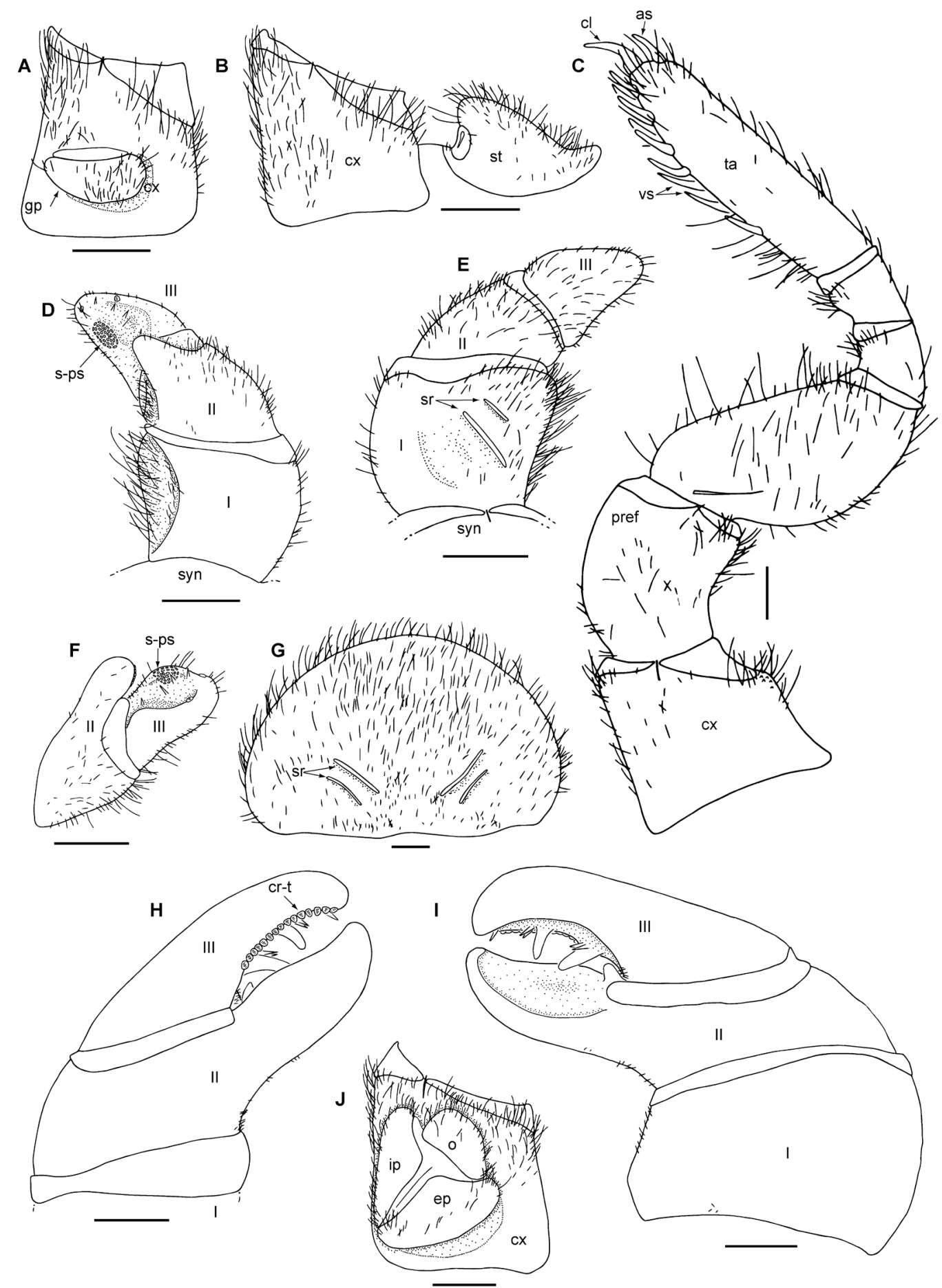

Fig. 6. Zoosphaerium silens sp. nov., holotype (FMNH-INS 3119887). A. Left coxa 2 with gonopore, posterior view. B. Left coxa 1 with stigmatic plate, posterior view. C. Left leg 9, posterior view. D. Left anterior gonopod, posterior view. E. Left anterior gonopod, anterior view. F. Left anterior gonopod, lateral view. G. Female subanal plate with washboard. H. Right posterior telopod, posterior view. I. Right posterior telopod, anterior view. J. Left female coxa 2 with vulva, posterior view. Abbreviations: as = apical spine; $\mathrm{cl}=\mathrm{claw} ; \mathrm{cr}-\mathrm{t}=$ crenulated teeth; $\mathrm{cx}=\mathrm{coxa} ; \mathrm{ep}=$ external plate; $\mathrm{gp}=$ gonopore; $\mathrm{ip}=$ inner plate $; \mathrm{o}=$ operculum; $\mathrm{pref}=$ prefemur; $\mathrm{s}-\mathrm{ps}=$ sclerotized spots $; \mathrm{sr}=$ stridulation rib $; \mathrm{st}=$ stigmatic plate; syn $=$ syncoxite; ta $=$ tarsus; $v s=$ ventral spines. Roman numerals indicate telopoditomeres. Scale bars $=1 \mathrm{~mm}$. 
Stigmatic Plates. First plate triangular, apex well rounded, nearly as wide as at base. Mesal margin slightly curved towards coxa. Hairs most abundant on apical margin, very few hairs on basal and lateral margins (Fig. 6B).

PLEURITES. First pleurite weakly modified, slightly extending posteriorly. Other pleurites well-rounded.

ColLum. Glabrous with very sparse setae around margins, mostly located at corners on either side of head.

THORACIC SHIELD. Smooth and glabrous, without protuberances.

TERGITES. Surface glabrous and matte, lacking small pits. Tips of paratergites of midbody tergites projecting posteriorly.

ENDOTERGUM. Inner section with numerous short triangular spines and very few longer setae. Middle area above spines with a single row of sparse elliptical cuticular impressions slightly varying in size. Apically two rows of dense marginal bristles, every second bristle strongly protruding above tergite margin (Fig. 5B). Bristles with numerous small spines.

ANAL SHIELD. Large and well-rounded. In both sexes glabrous. Underside lacking locking carinae.

LeGs. Leg 1 with 1 ventral spine, leg 2 with 1, leg 3 with 5 or 6 . First two leg pairs without an apical spine, spine present on leg 3. Leg pairs 4-21 with 8-10 ventral spines and an apical spine. On leg 9, femur 1.7 and tarsus 3.5 times as long as wide. All podomeres with setae (Fig. 6C).

\section{Male sexual characters}

GONOPORE. Covered with a single undivided, rounded membranous plate, very wide, located on basal half of coxa (Fig. 6A).

ANTERIOR TELOPODS. Harp with two weak stridulation ribs (Fig. 6E). First podomere with numerous setae mainly at lateral margin, as wide as long. Process of second podomere as long as basal fifth of third podomere, not visible in anterior view, with apical mound of a few sclerotized spots juxtaposed to third podomere. Third podomere with an apical sclerotized spot and a lateral crenulated tooth, mesally with an elevated area carrying sclerotized spots (Fig. 6D, F); lower area carrying 4 spines (Fig. 6D, F). Second and third podomeres sparsely setose.

POSTERIOR TELOPODS. Movable finger weakly curved; hollowed-out inner margin with two non-sclerotized lobes and ca five smaller sclerotized spines, posterior aspect with ca 15 large crenulated teeth. Fixed finger wider than movable finger, with slightly curved tip; basally with single membranous lobe, on inner margin covered with a few sclerotized spots. Second and third podomeres lacking long hair, almost completely glabrous. First podomere glabrous except for a few setae at mesal margin.

\section{Female sexual characters}

Washboard with two short interrupted stridulation ribs on each half(Fig. 6G). Vulva covering more than $2 / 3$ of coxa surface. Operculum large, ending before coxal margin. Apical margin of operculum wellrounded, reaching apicalmost point medially. Mesal plate reaching up to half of operculum's height (Fig. 6J).

\section{Distribution and ecology}

Zoosphaerium silens sp. nov. is currently known from the western dry forest of Kirindy-Mite as well as from the dry forest of Andranomena further north (Fig. 3). These populations differ by an uncorrected p-distance of $2.8 \%$ (Table 2). 


\section{Zoosphaerium coquerelianum species-group}

\section{Remarks}

Species can be identified as members of the Zoosphaerium coquerelianum species-group based on morphological characters of the posterior telopods (Wesener \& Wägele 2008; Wesener 2009). Telopoditomere 3 only carries small sclerotized teeth and is always slightly longer and $>1.5$ times as wide as the immovable finger. Similar telopod characters occur in some members of the Z. platylabum species-group, but the locking carinae in this group are located close to the last pleurites, while they are positioned close to the anal shield margin in species of the $Z$. coquerelianum group. The speciesgroup now contains 23 described species distributed in humid to subhumid forests all over Madagascar. Species of this group are conspicuously absent from the spiny forest ecosystem and the western dry forest (Wesener 2009; Wesener et al. 2010b; Sagorny \& Wesener 2017; Wesener \& Anilkumar 2020).

\section{Key to the species of the Zoosphaerium coquerelianum group}

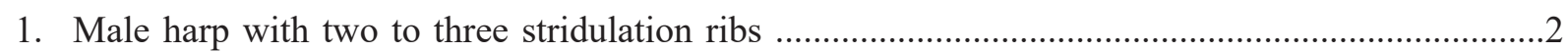

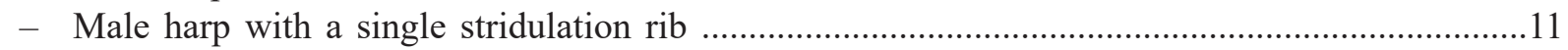

2. Tergites glossy, anteriorly shiny light green, posteriorly dark green. Specimen more than $50 \mathrm{~mm}$ long. Anal shield not well-rounded, with steep slope. Movable finger of posterior telopods 1.6 times as long as wide, apically with groove

Z. amabile Wesener, 2009

- Coloration pattern different, or if similar then specimens less than $35 \mathrm{~mm}$ long. Anal shield wellrounded or bell-shaped. Movable finger of posterior telopods 1.9-2.5 times as long as wide, without apical groove

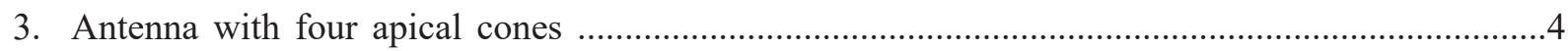

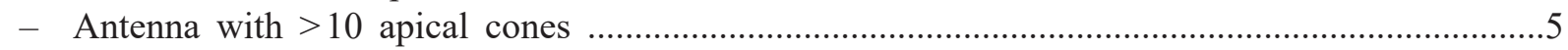

4. Anal shield surface covered with short hairs. Posterior locking carina of anal shield 2.5-3 times as long as anterior carina Z. alluaudi (de Saussure \& Zehntner, 1902)

- Anal shield surface glabrous. Posterior locking carina of anal shield more than 3.5 times as long as anterior carina Z. voeltzkowianum (de Saussure \& Zehntner, 1897)

5. Male harp with three stridulation ribs. Endotergum with three rows of marginal bristles, bristles slightly extending beyond tergite. Sclerotized teeth present on antennomeres 1-5. Movable finger of posterior telopods 2 times as long as wide. Posterior locking carina of anal shield four times as long as anterior carina. Male anal shield bell-shaped .......Z. trichordum Wesener, 2009

- Male harp with two stridulation ribs. Endotergum with one up to two rows of marginal bristles, bristles not reaching tergite margin. Sclerotized teeth only present up to antennomere 3 or 4 .....6

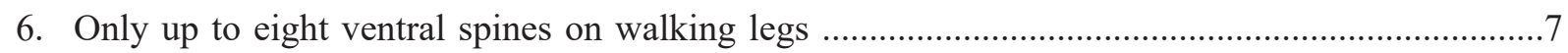

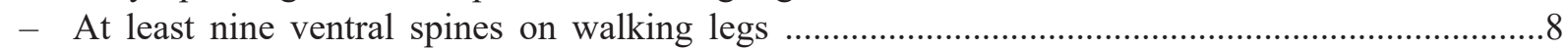

7. Movable finger of posterior telopod thick, 2.5 times as long as wide. Leg 3 with an apical spine. On anal shield, second locking carina 2-3 times as long as first ............ ambatovaky sp. nov.

- Movable finger of posterior telopod very thick, 2 times as long as wide. Leg 3 without an apical spine. On anal shield, second locking carina $4-5$ times as long as first

Z. muscorum Wesener \& Bespalova, 2010 
8. Male anal shield well-rounded, with slight bell shape. Posterior locking carina of anal shield six times as long as anterior carina. Up to 10 ventral spines on walking legs

Z. bambusoides Wesener \& Bespalova, 2010

- Male anal shield well-rounded. Posterior locking carina of anal shield three to four times as long as anterior carina. Usually more than 10 ventral spines on walking legs

9. Leg 3 without an apical spine. Specimens only slightly more than $30 \mathrm{~mm}$ long. Tergites jadelike green with thin brown posterior margin, texture glossy. Operculum of vulva deeply notched, strongly extending beyond coxa. Apical disc with ca 14 apical cones

Z. smaragdinum Wesener, 2009

- Leg 3 with an apical spine. Specimens more than $50 \mathrm{~mm}$ long. Tergites never jade-like, not glossy. Operculum of vulva not protruding above coxal margin. Apical disc with more than 20 apical cones

10. Specimens more than $60 \mathrm{~mm}$ long. Tergites dark-green, covered with numerous large pits and short setae. Sclerotized teeth present on antennomeres 1-3, disc with ca 45 apical cones. Endotergum with two rows of marginal bristles .........Z. villosum Wesener \& Sierwald, 2005

- Specimens less than $60 \mathrm{~mm}$ long. Tergites light-brown, glabrous. Sclerotized teeth present on antennomeres 1-4, disc with 20-30 apical cones. Endotergum with a single row of marginal bristles Z. bemanevika Sagorny \& Wesener, 2017

11. Movable finger 3 times as long as wide Z. ambrense Wesener, 2009

- Movable finger $<2.5$ times as long as wide

12. Antenna with four apical cones. Movable finger of posterior telopods at inner margin with two membranous lobes

- Antenna with >10 apical cones. Movable finger of posterior telopods at inner margin with a single membranous lobe

13. Process of second podomere of anterior telopod not visible in anterior view. Fifth antennomere with a field of sensilla basiconica. Collum with isolated, long setae. Endotergum with one row of large cuticular impressions and a second row of much smaller impressions; bristles long, strongly protruding above tergite Z. bilobum Wesener, 2009

- Process of second podomere of anterior telopod visible in anterior view

14. Podomere 3 of anterior telopod with crenulated teeth 15

- Podomere 3 of anterior telopod without crenulated teeth

15. Collum glabrous, with a few setae at corners on either side of head. Endotergum with two rows of regularly distributed circular impressions, marginal bristles strongly protruding above tergite. Sensilla basiconica present on antennomeres 1 and 2. Anal shield weakly bellshaped

Z. trigrioculatum Wesener \& Bespalova, 2010

- Collum glabrous, anterior margin with two rows of setae. Endotergum with a single row of elliptical cuticular impression, marginal bristles protruding to margin. Sensilla basiconica absent. Anal shield well rounded Z. bartolozzi Anilkumar \& Wesener, 2020

16. Collum glabrous. Endotergum with a single row of large cuticular impressions, marginal bristles slightly protruding above tergite margin. Second leg with 4 or 5 ventral spines. Anal shield tapering 
- Collum glabrous. Endotergum with a single row of slightly rounded elliptical cuticular impressions, marginal bristles protruding to margin. Second leg with 6 or 7 ventral spines. Anal shield well rounded Z. taiti Anilkumar \& Wesener, 2020

17. First pair of stigmatic plates greatly enlarged, with a well-rounded tip .18

- First pair of stigmatic plates triangular, tapering towards tip

18. Operculum of vulva ending clearly before coxal margin, deeply notched, divided into two large, well-rounded, similar-sized lobes. Third podomere of anterior telopod laterally with ca five large sclerotized teeth. Sensilla basiconica on first antennomere absent. Posterior locking carina of anal shield two times as long as anterior carina. Endotergal marginal bristles protruding up to tergite margin. Movable finger of posterior telopods thick, 1.9 times as long as wide ......Z. tampolo Wesener, 2009

- Operculum of vulva ending before coxal margin, elongated into a single median lobe, lobe only shallowly notched at tip. Third podomere of anterior telopod without any large sclerotized teeth. Sensilla basiconica on first antennomere present. Locking carinae of anal shield of equal length. Endotergal marginal bristles very short, ending far before tergite margin. Movable finger of posterior telopods thick, 2.1 times as long as wide

Z. ignotum Wesener, 2009

19. Tergite texture orange-peel like. Collum covered with isolated, long hairs. Body size of adult female $>50 \mathrm{~mm}$. Endotergum with two rows of marginal bristles and a single row of large circular cuticular impressions

- Tergite texture glossy or smooth. Collum glabrous. Body size of adults $<35 \mathrm{~mm}$. Endotergum with a single row of marginal bristles and either without or with two rows of cuticular impressions

20. Posterior locking carina on anal shield 2.5 times as long as anterior carina. Third podomere of anterior telopods without large sclerotized teeth. Anal shield glabrous

Z. coquerelianum (de Saussure \& Zehntner, 1897)

- Posterior locking carina on anal shield $>4$ times as long as anterior carina. Third podomere of anterior telopods with at least three large sclerotized teeth. Anal shield covered with short hair

21. Third podomere on anterior telopods with 3 or 4 crenulated teeth. Endotergal marginal bristles very short, protruding up to $1 / 3$ of distance to tergite margin. Tips of vulvar operculum widely separated Z. mangabe Wesener, 2020

- Third podomere on anterior telopods with ca seven large sclerotized teeth. Endotergal marginal bristles protruding up to tergite margin. Tips of vulvar operculum fused

Z. tainkintana Wesener, 2009

22. Tergites glossy. Female anal shield bell-shaped, in male with steep slope. Fixed finger of posterior telopods wide, only slightly curved towards movable finger. Movable finger 1.8 times as long as wide, on posterior side with ten small sclerotized teeth. Sclerotized teeth on antenna only present on first antennomere. Endotergum without cuticular impressions .........Z. viridissimum Wesener, 2009

- Tergites matte. Anal shield well-rounded. Fixed finger of posterior telopods slender, strongly curved towards movable finger. Movable finger 2.4 times as long as wide, on posterior side with ca 25 small sclerotized teeth. Sclerotized teeth present on antennomeres 1-3. Endotergum with a single row of large and a second row of smaller circular cuticular impressions 


\section{Zoosphaerium ambatovaky sp. nov. urn:1sid:zoobank.org:act:42C1A931-D533-4FF6-B76A-CAB8F7E1461D}

Figs 2C, 3, 5C, 7

\section{Diagnosis}

The presence of only 7 or 8 ventral spines on the walking legs in Z. ambatovaky sp. nov., especially in combination with a glossy green color, two stridulation ribs on the male harp and more than 10 apical cones on the antenna, is only shared with $Z$. muscorum Wesener \& Bespalova, 2010. The new species differs from Z. muscorum in the presence of an apical spine on the third leg pair (absent in Z. muscorum), the movable finger of the posterior telopod being 2.5 times as long as wide ( 2 times as long as wide in Z. muscorum) and the second locking carina of the anal shield being $2-3$ times as long as the first (4-5 times as long as the first in Z. muscorum).

\section{Etymology}

'Ambatovaky', noun in apposition, after the forest of Ambatovaky, the only known locality for this species (Fig. 3).

\section{Material examined}

\section{Holotype}

MADAGASCAR - Toamasina - Ō; Rés. Speciale Ambatovaky, Sandrangato River; $16^{\circ} 46^{\prime 2} 22^{\prime \prime}$ S, 49¹5'56" E; alt. 450 m; rainforest; 20 Feb. 2010; B.L. Fisher et al. leg.; coll. no. BLF24311; CASENT 9068294/1.

\section{Description}

\section{Male}

BoDy LENGTH. Holotype male: length ca $44 \mathrm{~mm}$, width of thoracic shield $23.1 \mathrm{~mm}$, of tergite $524.4 \mathrm{~mm}$ (widest), height of thoracic shield $14.1 \mathrm{~mm}$ (highest).

Coloration. Some discoloration may have occurred because of preservation in ethanol. Head, collum, thoracic shield and tergites shiny green with a conspicuous narrow light posterior margin (Fig. 2C). Anal shield of a different color, jade-like green. Antennae green, legs basally dark green, apically brownish.

HEAD. Eyes with $>95$ ommatidia. Antennae long, with cylindrical joints, protruding posteriorly to leg pair 4. Length of antennomeres $1>2>3=4=5<6$. A shallow groove present on antennomere 1. Male apical disc with 45/35 apical sensory cones. Organ of Tömösváry located in antennal groove.

GNATHOCHILARIUM AND MANDIBLE. Not dissected.

Stigmatic Plates. First stigmatic plate triangular, apex well rounded, nearly as wide as at base, slightly turned towards coxa. Hair most abundant on apical margin, very few hairs on basal and lateral margins (Fig. 7C).

PLEURITES. First pleurite well-rounded, not projecting.

Collum. Glabrous.

THORACIC SHIELD. Smooth and glabrous, without protuberances. 


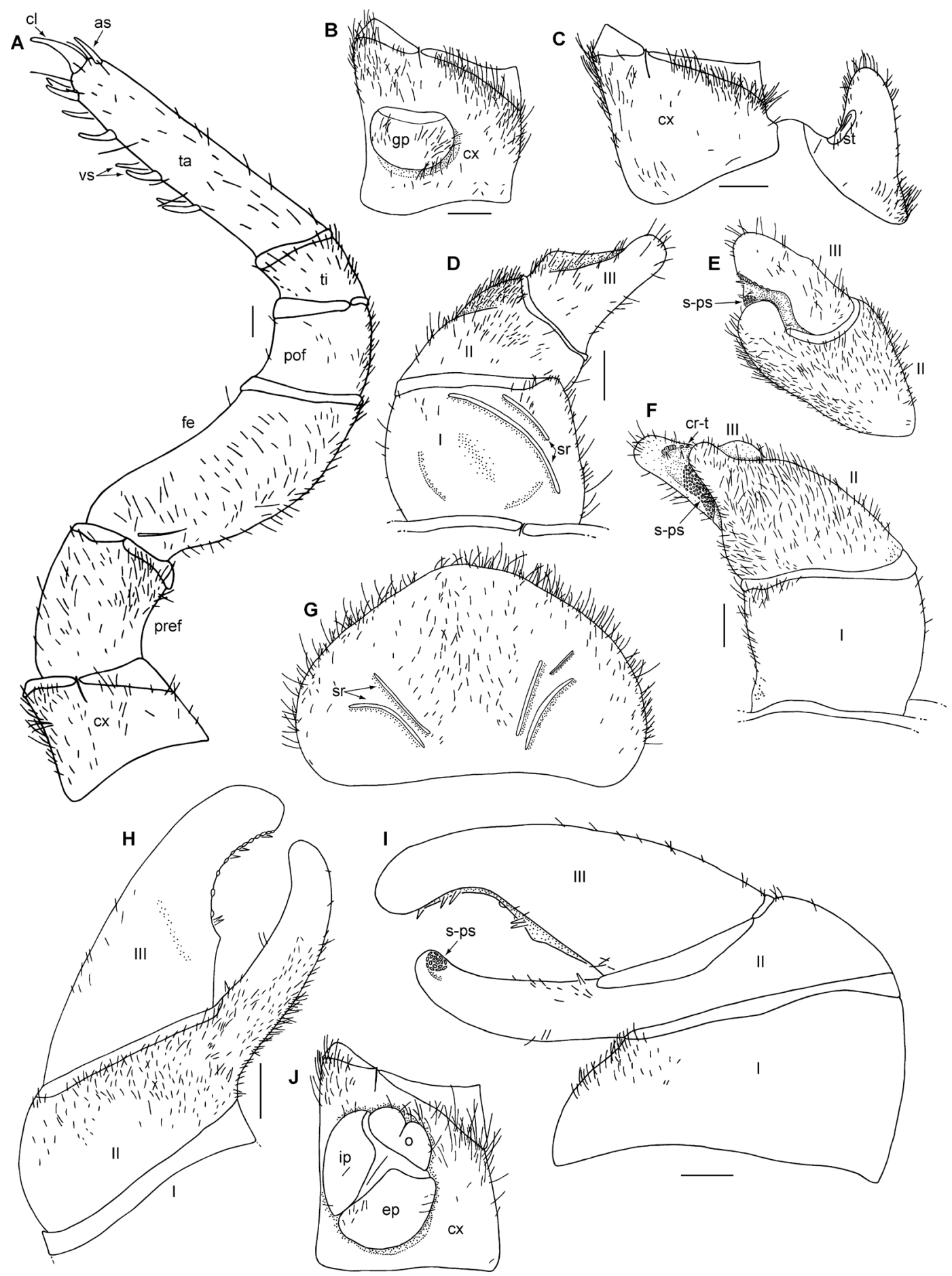

Fig. 7. Zoosphaerium ambatovaky sp. nov., holotype (CASENT 9068291). A. Left leg 9, posterior view. B. Left coxa 2 with gonopore, posterior view. C. Left coxa 1 with stigmatic plate, posterior view. D. Left anterior gonopod, anterior view. E. Left anterior gonopod, posterior view. F. Left anterior gonopod, lateral view. G. Left female coxa 2 with vulva, posterior view. H. Female subanal plate with washboard. I. Right posterior telopod, posterior view. J. Right posterior telopod, anterior view. Abbreviations: as = apical spine; $\mathrm{cl}=$ claw; $\mathrm{cr}-\mathrm{t}=$ crenulated teeth; $\mathrm{cx}=\mathrm{coxa}$; $\mathrm{ep}=$ external plate; $\mathrm{fe}=$ femur; gp = gonopore; ip = inner plate; o = operculum; pof $=$ postfemur; pref $=$ prefemur; $\mathrm{s}-\mathrm{ps}=$ sclerotized spots; $\mathrm{sr}=$ stridulation rib; $\mathrm{st}=$ stigmatic plate; ta $=$ tarsus; $\mathrm{t} i=$ tibia; vs = ventral spines. Roman numerals indicate telopoditomeres. Scale bars $=1 \mathrm{~mm}$. 
Tergites. Surface glabrous and shiny, lacking small pits. Tips of paratergites of midbody tergites projecting posteriorly.

ENDOTERGUM. Inner section with numerous short triangular spines and longer setae. Middle area above spines with a single row of sparse circular cuticular impressions slightly varying in size. Apically with $1-2$ rows of short marginal bristles, protruding to $2 / 3$ of distance of tergite margin (Fig. 5C). Bristles with numerous small spines.

ANAL SHIELD. Male anal shield bell-shaped, without hairs, glabrous. Underside with two black locking carinae, posterior one 2-3 times as long as anterior one, both located close to anal shield margin.

LeGs. Leg 1 with 4 ventral spines, leg 2 with 6 or 7 , leg 3 with 6 . First two leg pairs without an apical spine, spine present on leg 3. Leg pairs 4-21 with 7 or 8 ventral spines and an apical spine. On leg 9, femur 2 and tarsus 4.5 times as long as wide. All podomeres with setae (Fig.).

\section{Male sexual characters}

GONOPORE. Covered with a single undivided, rounded membranous plate, covering $1 / 4$ of surface of coxa. Gonopore located on basal half of joint (Fig. 7B).

ANTERIOR TELOPODS. Harp with two stridulation ribs, one long and well pronounced rib located laterally of a less pronounced and shorter mesal rib (Fig. 7D). First podomere with only a few setae, restricted to apical parts of lateral margins, 1.5 times as wide as long. Process of second podomere nearly as long as basal $2 / 3$ of third podomere, not visible in anterior view, and with an apical mound of a few sclerotized spots juxtaposed to third podomere (Fig. 7E-F). Third podomere with an apical brown sclerotized spot and a field of elevated sclerotized spots at inner margin below brown spot; two small spines located below sclerotized spot (Fig. 7F); depression lateral to field of spots with one small sclerotized spine, lateral margin with up to 6 crenulated teeth (Fig. 7E-F). Second podomere densely setose, third podomere with setae mainly apically and laterally.

POSTERIOR TELOPODS. Movable finger (podomere 3) 2.5 times as long as wide, weakly curved towards immovable finger (process of podomere 2). Shallowly hollowed-out inner margin with five sclerotized spines, three positioned apically and two in middle of cavity next to small membranous lobe. Additional sclerotized spine at base of movable finger. Posterior aspect with ca 12 small crenulated teeth (Fig. 7H). Immovable finger thinner and shorter than movable finger, curved towards the latter. Sclerotized spine located on anterior side near base of immovable finger. Inner part of immovable finger apically covered with a few sclerotized spots (Fig. 7I). Movable finger glabrous on both sides except for a few hairs basolaterally. Second podomere in posterior view setose, in anterior view with a few setae on finger.

\section{Female}

Unknown.

\section{Distribution and ecology}

Zoosphaerium ambatovaky sp. nov. is currently known only from the type locality, a lowland rainforest close to the Ille Sainte Marie (Fig. 3). This species seems to be closely related to Z. muscorum from the montane forest of Anjanaharibe-Sud, the only species with which it shares the presence of only 7 or 8 ventral spines on the walking legs, as well as a glossy green color, two stridulation ribs on the male harp and more than 10 apical cones on the antenna. A female Zoosphaerium from the same forest (CASENT 9068291B) belongs to a different species. The forest of Ambatovaky is isolated and shrinking rapidly (Rakotondrasoa et al. 2017). 


\section{Zoosphaerium platylabum species-group}

\section{Remarks}

Species can be identified as members of the Zoosphaerium platylabum species-group based on the number of locking carinae (always 2) of the anal shield that are located close to the last pleurite, as well as on morphological characters of the female vulva, whose apical processes are usually sharpedged (with the exception of those in Z. tsingy Wesener, 2009). The posterior telopods (Wesener \& Wägele 2008) show two vastly different modifications: the movable finger is either very thick, or quite elongated and slender. The species-group now contains $6+3$ described species distributed in humid as well as western dry forests all over Madagascar. Species of this group are conspicuously absent from the southern spiny forest ecosystem (Wesener 2009).

\section{Key to species of the Zoosphaerium platylabum species-group}

1. Movable finger of posterior telopods very thick, $<2$ times as long as wide, width strongly decreasing towards tip; apically with minute sclerotized nubs on posterior as well as on anterior side

- Movable finger slender, at least 3 times as long as wide, width not decreasing towards tip; apically sclerotized structures only present on posterior side

2. Movable finger 1.2 times as long as wide, at inner margin with a small membranous lobe. First stigmatic plate greatly enlarged, lobe not triangular or tapering towards tip. Antenna with more than 35 apical cones

Z. platylabum (de Saussure \& Zehntner, 1902)

- Movable finger 1.6 times as long as wide, at inner margin without lobe. First stigmatic plate large, lobe triangular and tapering towards well-rounded tip. Antenna with 23-35 apical cones ..

.Z. pseudoplatylabum Wesener, 2009

3. Anterior edges of thoracic shield slightly projecting towards head. Movable finger shorter than fixed finger Z. solitarium Wesener, 2009

- Anterior edges of thoracic shield well-rounded. Movable finger at least slightly longer than fixed finger

4. Male harp with two stridulation ribs. Movable finger 3 times as long as wide .....................5

- Male harp with a single stridulation rib. Movable finger $>4$ times as long as wide ................7

5. Movable finger on posterior telopods with five spines and no membranous lobes. Immovable finger of posterior telopod slender, 4 times as long as wide, apical part tapering and curved towards movable finger. Only 7 or 8 ventral spines on legs. Found in eastern rainforests, Masoala Peninsula

Z. masoala sp. nov.

- Movable finger on posterior telopods with spines and at least one large, triangular membranous lobe. Immovable finger of posterior telopod wide, 2.7 times as long as wide, not curved, parallel to movable finger, apically only weakly tapering. 10 or more ventral spines on legs. Found in western dry forests

6. Light brown. Antennae with four apical cones. Third podomere of anterior telopods lacking crenulated teeth

Z. beanka sp. nov.

- Olive green. Antennae with $>15$ apical cones. Third podomere of anterior telopods laterally with 2 or 3 crenulated teeth

Z. tsingy Wesener, 2009

7. Tergites shiny black, appendages red. Anal shield strongly developed, shaped like a helmet. Fixed finger of posterior telopod slightly curved towards movable finger. Operculum of vulva 
deeply notched, divided into two sharp 'horns'. Female washboard on each side with a single stridulation rib

- Tergites light brown or olive-brownish, appendages brown or green. Anal shield well-rounded. Fixed finger of posterior telopod parallel to movable finger

8. Up to $30 \mathrm{~mm}$ long. Movable finger of posterior telopod with 25 teeth, three spines located at apex. Endotergum with two dense rows of long marginal bristles, protruding above tergite margin. (Female unknown)

Z. voahangy sp. nov.

- Up to $55 \mathrm{~mm}$ long. Movable finger of posterior telopod with ca 15 teeth, three spines located at regular intervals along entire margin. Endotergum with a single row of short, dense marginal bristles, protruding up to $2 / 3$ of distance towards tergite margin. Operculum of vulva only very shallowly notched, forming two sharp horns. Female washboard with four stridulation ribs

Z. broelemanni Wesener, 2009

\section{Zoosphaerium beanka sp. nov. urn:1sid:zoobank.org:act:7F9589AA-AD5D-473F-A7C1-FB94F30FF8AD}

Figs 2D, 3, 5D, 8

\section{Diagnosis}

The shape and position of the locking carinae place Z. beanka sp. nov. in the Z. platylabum speciesgroup, but the telopods of $Z$. beanka sp. nov. have almost no similarities to those of any other described giant pill-millipede species except $Z$. tsingy. Both species share characters of the posterior telopods, namely the presence of spines and at least one large membranous lobe on the movable finger, and an uncurved, wide immovable finger (2.7 times as long as wide) that is parallel to the movable finger. Zoosphaerium beanka sp. nov. differs from the latter in the light brown color (olive in Z. tsingy), the presence of only four apical cones on the antenna (>15 in Z. tsingy) and the differently shaped anterior telopods, in which telopoditomere 3 lacks crenulated teeth (present in Z. tsingy).

\section{Etymology}

'Beanka', noun in apposition, after the type and only known locality for this species, the dry forest of Beanka (Fig. 3).

\section{Material examined}

Holotype

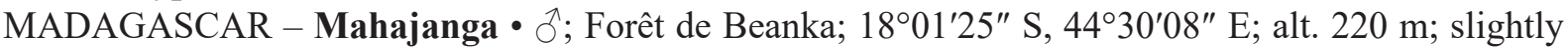
disturbed dry deciduous forest; 14 Jan. 2010; Z.H. Harimpitia leg.; coll. no. Z.H.H-031; FMNH-INS 3119897.

\section{Description}

BoDy LENGTH. Male (holotype): length $36.7 \mathrm{~mm}$, width of thoracic shield up $22.1 \mathrm{~mm}$ (widest), height of thoracic shield $11.8 \mathrm{~mm}$ (highest).

Coloration. Head, collum, thoracic shield, tergites and anal shield light brown (Fig. 2D). Antennae green, legs light brown.

HEAD. Eyes with more than 75 ommatidia. Antennae short, protruding back to leg 3. Length of antennomeres $1>2=3=4=5<6$. A shallow groove present on antennomere 1 , disc with 4 apical cones.

GNATHOCHILARIUM AND MANDIBLE. Not dissected. 


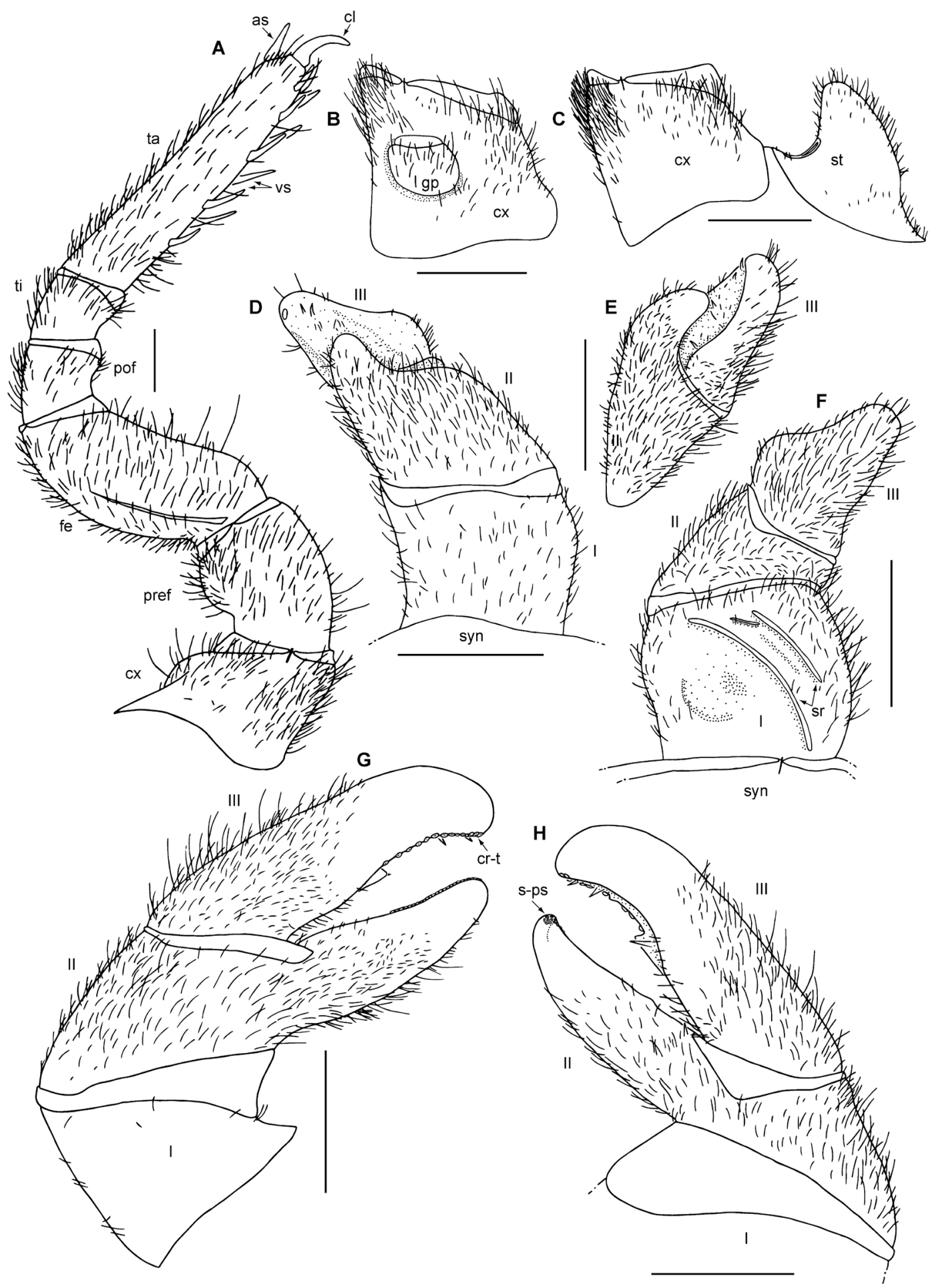

Fig. 8. Zoosphaerium beanka sp. nov., holotype (FMNH-INS 3119906). A. right leg 9, posterior view. B. Left coxa 2 with gonopore, posterior view. C. Left coxa 1 with stigmatic plate, posterior view. D. Left anterior gonopod, posterior view. E. Left anterior gonopod, lateral view. F. Left anterior gonopod, anterior view. G. Right posterior telopod, posterior view. H. Right posterior telopod, anterior view. Abbreviations: $\mathrm{as}=$ apical spine; $\mathrm{cl}=\mathrm{claw} ; \mathrm{cr}-\mathrm{t}=$ crenulated teeth; $\mathrm{cx}=\mathrm{coxa} ; \mathrm{fe}=$ femur; $\mathrm{gp}=$ gonopore; pof $=$ postfemur; pref $=$ prefemur; $s-p s=$ sclerotized spots; $s r=$ stridulation rib; $s t=$ stigmatic plate; syn $=$ syncoxite; $\mathrm{ta}=$ tarsus; $\mathrm{t} i=$ tibia; $\mathrm{vs}=$ ventral spines. Roman numerals indicate telopoditomeres. Scale bars $=1 \mathrm{~mm}$. 
Stigmatic Plates. First stigmatic plate triangular, apex well rounded, nearly as wide as at base, slightly turned towards coxa. Hairs most abundant on apical margin, very few hairs on basal and lateral margins (Fig. 8C).

PleURITES. First pleurite slightly extending posteriorly in a well-rounded process.

CoLLum. Margins covered with a few short hairs, central part glabrous.

THORACIC SHIELD. Surface like those of tergites, glabrous.

TERGITES. Smooth and glabrous, no small pits present. Paratergites projecting slightly posteriorly.

ENDOTERGUM. Inner section with numerous short spines and isolated bristles. Between marginal ridge and inner area, a single row of sparse large, circular cuticular impressions. Externally one or two rows of marginal bristles, standing irregularly to each other. Bristles scaly, of medium length, longest reaching slightly above tergite margin (Fig. 5D).

ANAL SHIELD. Rounded, neither bell-shaped nor tapered, glabrous. Ventral side of anal shield with two black locking carinae, located close to laterotergites. Anterior carina small, posterior carina 2-3 times as long as anterior carina.

LeGs. Leg 1 with 6 or 7 ventral spines, leg 2 with 8 , leg 3 with 10. First two leg pairs without an apical spine, spine present on leg 3. Leg pairs 4-21 with 9 or 10 ventral spines and an apical spine. On leg 9, femur 2 and tarsus 4.9 times as long as wide. All podomeres with setae (Fig. 8A).

\section{Male sexual characters}

GONOPORE. Covered with a single undivided, rounded membranous plate, covering 1/4 of surface of coxa. Gonopore located centrally on joint (Fig. 8B).

ANTERIOR TELOPODS. Harp with two stridulation ribs, mesal rib smaller than lateral one, both ribs well developed (Fig. 8F). First podomere 1.2 times as wide as long. Second podomere process lobe-like and slightly curved, with rounded edges, protruding up to half of third podomere height, apically with sclerotized spots. Third podomere long, as long as first; cavity mesally with numerous sclerotized spots and three thin, sclerotized spines; one sclerotized spot located close to tip. Podomeres 1-3 covered on both sides with numerous long, isolated hairs.

Posterior TELOPODS. Movable finger with a well-rounded tip, not tapering towards tip; hollowed-out inner margin with one non-sclerotized lobe and 3 or 4 sclerotized spines, posterior aspect with ca 14 small sclerotized teeth. Movable finger slightly longer than fixed finger, the latter straight, as wide as third podomere. Fixed finger at margin with numerous sclerotized spots. All podomeres covered on both sides with numerous, long isolated hairs, only tips of chela glabrous (Fig. 8G-H).

\section{Female}

Unknown.

\section{Distribution and ecology}

Zoosphaerium beanka sp. nov. is currently known only from the dry forest of Beanka (Fig. 3). With most known dry forest giant pill-millipede species being widespread (Wesener \& Wägele 2008; Wesener 2009), this species can be expected in surrounding dry forest fragments. 


\section{Zoosphaerium voahangy sp. nov. urn:1sid:zoobank.org:act:11B9C806-A111-48FC-AC36-035385125232}

Figs 2E, 3, 5E, 9

\section{Diagnosis}

The position of the locking carinae close to the last pleurite identifies $Z$. voahangy sp. nov. as a member of the $Z$. platylabum species-group. The uniquely slender and elongated posterior telopods in combination with the presence of a single stridulation rib on the male harp and more than 35 apical cones on the antennae, are characters only shared with Z. broelemanni Wesener, 2009. Zoosphaerium voahangy sp. nov. differs from $Z$. broelemanni in the differently shaped anterior telopods, spination and teeth number of the movable finger of the posterior telopod (see key), as well as in characters of the endotergum, which has two dense rows of long marginal bristles in the former, but a single row of short bristles in the latter.

\section{Etymology}

'Voahangy', noun in apposition, to honor the great collector and Malagasy scientist Voahangy Soarimalala.

\section{Material examined}

\section{Holotype}

MADAGASCAR - Mahajanga - ó; Analalava, $5.5 \mathrm{~km}$ NNE of Ambinda Village; $14^{\circ} 18.6^{\prime} \mathrm{S}$, 4754.9' E; alt. 120 m; dry deciduous forest; 8 Dec. 2004; V. Soarimalala leg.; coll. no. VS-508; FMNHINS 3119921.

\section{Paratype}

MADAGASCAR - Mahajanga • đ̇; same collection data as for holotype; FMNH-INS 3119919.

\section{Description}

BoDy LENGTH. Male (holotype): length $26.3 \mathrm{~mm}$, width of thoracic shield $16.1 \mathrm{~mm}$, of tergite $716.7 \mathrm{~mm}$ (widest), height of thoracic shield $8.9 \mathrm{~mm}$, of tergite $79.3 \mathrm{~mm}$ (highest).

Coloration. Head, collum, thoracic shield and tergites light brown with dark posterior margins. Anal shield entirely light brown (Fig. 2E). Antennae dark green, legs basally light brown, apically green.

HEAD. Eyes with more than 65 ommatidia. Antennae short, protruding back to leg 5. Length of antennomeres $1=2=3=4=5<6$. A shallow groove present on antennomere 1 , disc with 48/49 apical cones.

GNaTHOCHILARIUM AND MANDIBLE. Not dissected.

Stigmatic Plates. First stigmatic plate triangular, apex sharply edged, pointed, turned towards coxa. Hairs most abundant on apical margin (Fig. 9C).

Pleurites. First pleurite extending posteriorly in a well-rounded process. Second pleurite also with a well-rounded process, but not projecting. Remaining pleurites broadly rounded.

Collum. Margins with a few short hairs, central part glabrous.

THORACIC SHIELD. Surface like those of tergites, glabrous.

TERGITES. Smooth and glabrous, no small pits present. Paratergites projecting slightly posteriorly. 


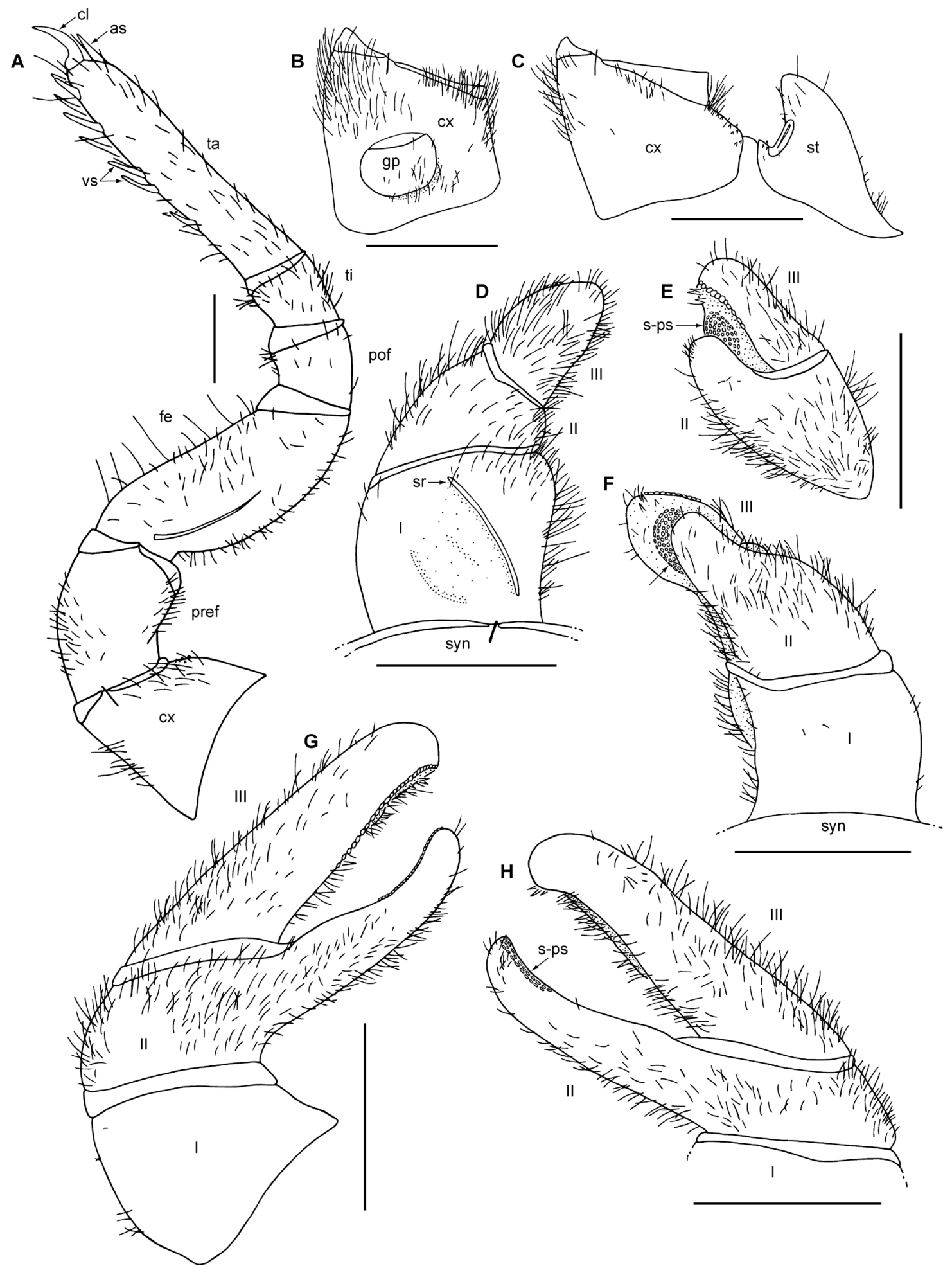

Fig. 9. Zoosphaerium voahangy sp. nov., holotype (FMNH-INS 3119921). A. left leg 9, posterior view. B. Left coxa 2 with gonopore, posterior view. C. Left coxa 1 with stigmatic plate, posterior view. D. Left anterior gonopod, anterior view. E. Left anterior gonopod, lateral view. F. Left anterior gonopod, posterior view. G. Right posterior telopod, posterior view. H. Right posterior telopod, anterior view. Abbreviations: $\mathrm{as}=$ apical spine; $\mathrm{cl}=$ claw; $\mathrm{cx}=\mathrm{coxa}$; $\mathrm{fe}=$ femur; $\mathrm{gp}=$ gonopore; pof $=$ postfemur; pref $=$ prefemur; s-ps = sclerotized spots; $\mathrm{sr}=$ stridulation $\mathrm{rib} ; \mathrm{st}=$ stigmatic plate; syn $=$ syncoxite; ta $=$ tarsus; $\mathrm{ti}=$ tibia; $\mathrm{vs}=$ ventral spines. Roman numerals indicate telopoditomeres. Scale bars $=1 \mathrm{~mm}$. 
ENDOTERGUM. Inner section with numerous short spines and isolated bristles. Between marginal ridge and inner area a single row of sparse, circular cuticular impressions. Externally two dense rows of marginal bristles. Bristles scaly, the longest reaching above tergite margin (Fig. 5E).

ANAL SHIELD. Rounded, neither bell-shaped nor tapered, glabrous. Ventral side with two black locking carinae, located closely to laterotergites. Anterior carina small and posterior carina 2-3 times as long as anterior carina.

LEGS. Leg 1 with 4 ventral spines, leg 2 with 5 or 6 , leg 3 with 7. First two leg pairs without an apical spine, spine present on leg 3 . Leg pairs 4-21 with 9 or 10 ventral spines and an apical spine. On leg 9, femur 2.1 and tarsus 5.1 times as long as wide. All podomeres with setae (Fig. 9A).

\title{
Male sexual characters
}

GONOPORE. Covered with a single undivided, apically rounded, membranous, basally sclerotized plate covering $1 / 4$ of surface of coxa. Gonopore located basally on joint (Fig. 9B).

ANTERIOR TELOPODS. Harp with single stridulation rib located mesally, long and well developed (Fig. 9D). First podomere 1.1 times as wide as long. Second podomere process lobe-like and slightly curved with rounded edges, protruding up to half of third podomere height, apically with sclerotized spots (Fig. 9F). Third podomere long, almost as long as first; cavity mesally with numerous sclerotized spots and three thin, sclerotized spines located apically (Fig. 9E-F); one sclerotized spot located close to tip, laterally with a row of ca 11 crenulated teeth (Fig. 9E). Podomeres 1-3 covered on both sides with numerous long, isolated hairs.

POSTERIOR TELOPODS. Movable finger slender and long, with a well-rounded tip, not tapering towards tip; hollowed-out inner margin with 3 or 4 sclerotized spines located apically, posterior aspect with ca 25 small sclerotized teeth (Fig. 9G). Movable finger 4 times as long as wide, slightly longer than fixed finger. Fixed finger straight, only apically curved towards movable finger, not tapering, more slender than third podomere. Fixed finger at margin with numerous sclerotized spots (Fig. 9H). First podomere in posterior view almost glabrous, podomeres 2 and 3 covered on both sides with numerous long, isolated hairs.

\section{Female}

Unknown.

\section{Distribution and ecology}

The only known habitat of $Z$. voahangy sp. nov., the forest of Analalava (Fig. 3), is a small (2 km south to north, $750 \mathrm{~m}$ east to west) fragment of disturbed and partly degraded lowland rainforest, isolated by $30 \mathrm{~km}$ from Betampona, the only other remaining lowland rainforest fragment in a $100 \mathrm{~km}$ radius.

\author{
Zoosphaerium masoala sp. nov. \\ urn:lsid:zoobank.org:act:F62E0E9E-172D-4076-BD01-509AD42BAE89
}

Figs 2F, 3, 10A, 11

\section{Diagnosis}

The shape and position of the locking carinae, as well as the slender posterior telopods place Z. masoala sp. nov. in the Z. platylabum species-group. Zoosphaerium masoala sp. nov. differs from all other species of the group in the combination of the presence of two stridulation ribs on the male harp, slender posterior telopods in which both fingers reach almost the same length and $>10$ apical cones on the antenna. 


\section{Etymology}

'Masoala', noun in apposition, after the forest and peninsula of Masoala, the largest remaining area of lowland rainforest on Madagascar, for which the species described here is the first recorded giant pillmillipede species (Fig. 3).

\section{Material examined}

\section{Holotype}

MADAGASCAR - Toamasina • đ’; Région Sava, Parc National de Masoala, Forêt de Tampolo, $1.2 \mathrm{~km}$ $\mathrm{S}$ of Ambodiforaha village; $15^{\circ} 43^{\prime} 45.6^{\prime \prime} \mathrm{S}, 49^{\circ} 57^{\prime} 49.4^{\prime \prime} \mathrm{E}$; alt. $15 \mathrm{~m}$; pitfall buckets, littoral forest; 11 Dec. 2015; V. Soarimalala leg.; coll. no. VS-2582; FMNH-INS 3195651.

\section{Description}

\section{Male}

Body LENGTH. Length $23.9 \mathrm{~mm}$, width of thoracic shield $14.2 \mathrm{~mm}$ (widest), height of thoracic shield $7.2 \mathrm{~mm}$ (highest).

Coloration. Head, collum, thoracic shield and tergites dark brown to black. Grooves of thoracic shield greenish, anal shield lighter brown (Fig. 2F). Antennae and legs green.

HEAD. Eyes with more than 50 ommatidia. Antennae short, protruding back to leg 4 . Length of antennomeres $1>2>3=4=5<6$. A shallow groove present on antennomere 1 , disc with $33 / 12$ apical cones.

\section{GNATHOCHILARIUM AND MANDIBLE. Not dissected.}

Stigmatic Plates. First stigmatic plate triangular, apex well-rounded, slender, curved towards coxa. Hair most abundant on apical margin (Fig. 11C).
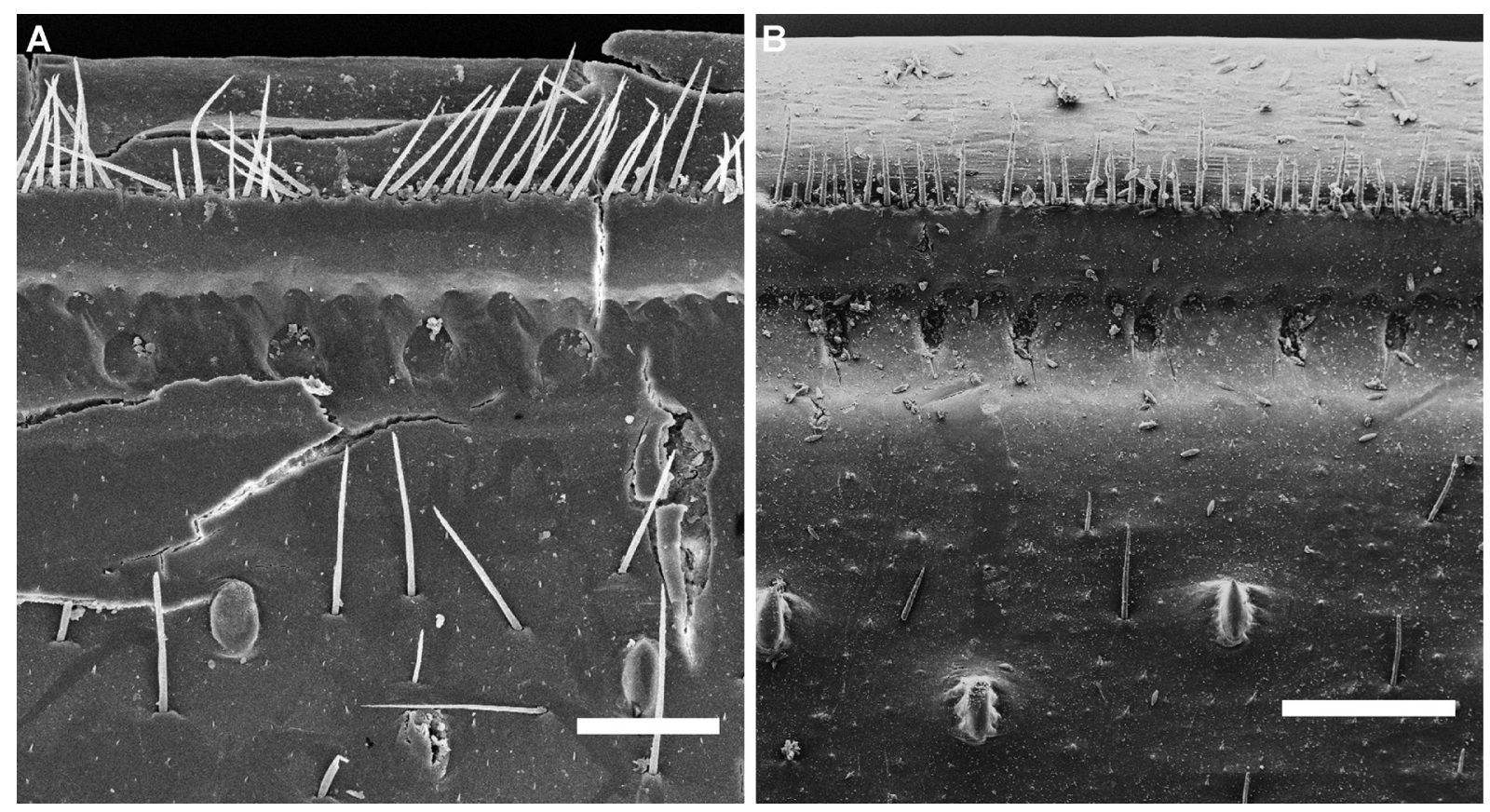

Fig. 10. Scanning electron micrographs of the endoterga of midbody rings. A. Zoosphaerium masoala sp. nov., holotype (FMNH-INS 3195651). B. Z. spinopiligerum sp. nov., holotype (FMNH-INS 3119885). Scale bars $=100 \mu \mathrm{m}$. 


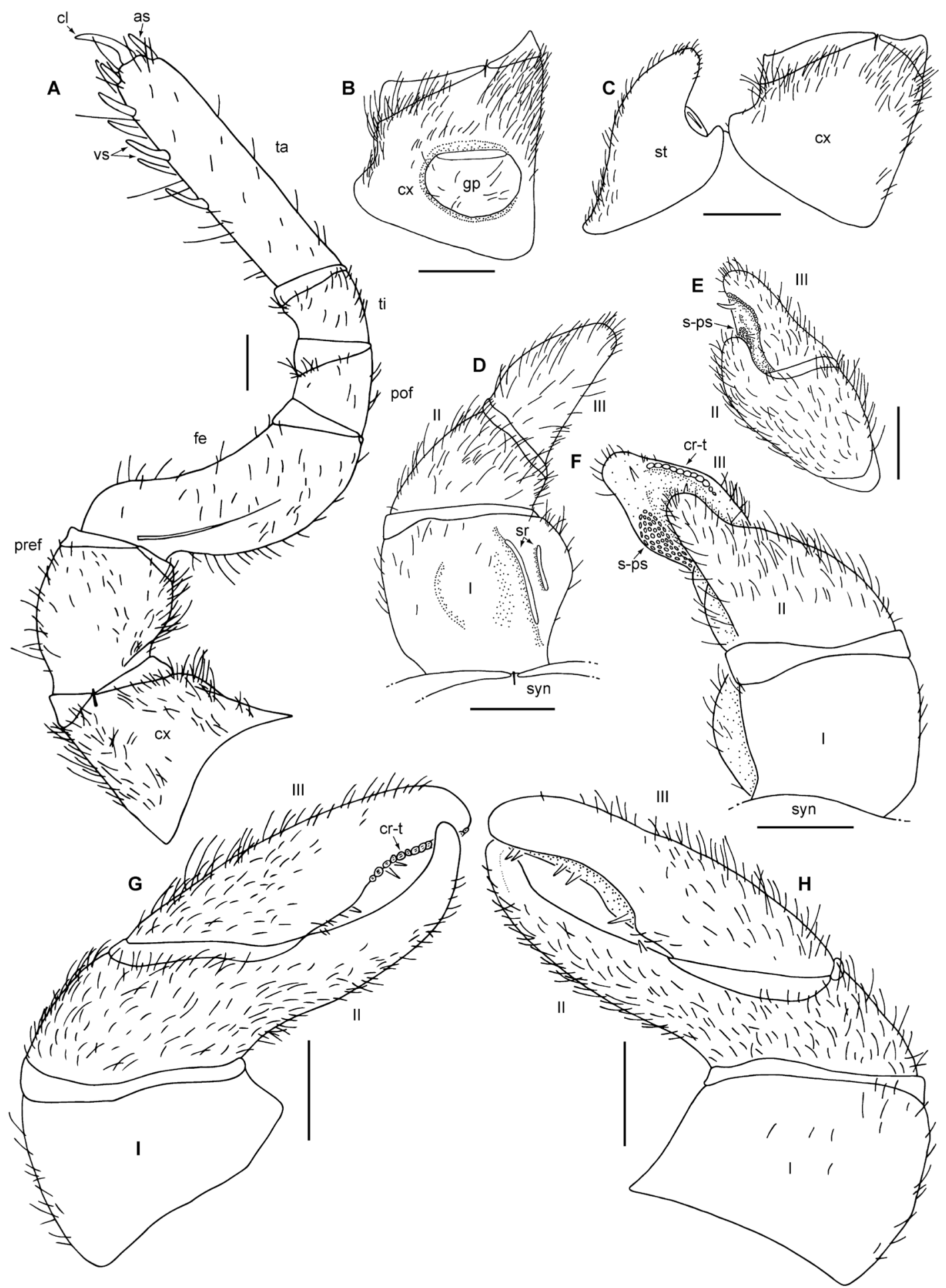

Fig. 11. Zoosphaerium masoala sp. nov., holotype (FMNH-INS 3195651). A. Left leg 9, posterior view. B. Right coxa 2 with gonopore, posterior view. C. Right coxa 1 with stigmatic plate, posterior view. D. Left anterior gonopod, anterior view. E. Left anterior gonopod, lateral view. F. Left anterior gonopod, posterior view. G. Right posterior telopod, posterior view. H. Right posterior telopod, anterior view. Abbreviations: as = apical spine; $\mathrm{cl}=\mathrm{claw} ; \mathrm{cr}-\mathrm{t}=$ crenulated teeth; $\mathrm{cx}=\mathrm{coxa} ; \mathrm{fe}=$ femur; $\mathrm{gp}=$ gonopore; pof $=$ postfemur; pref $=$ prefemur; s-ps $=$ sclerotized spots; $s r=$ stridulation rib; $s t=$ stigmatic plate; syn $=$ syncoxite; $\mathrm{ta}=$ tarsus; $\mathrm{t} \mathrm{i}=$ tibia; $\mathrm{vs}=$ ventral spines. Roman numerals indicate telopoditomeres. Scale bars $=1 \mathrm{~mm}$. 
PLeuRITES. First pleurite extending slightly posteriorly in a long, thin process.

Collum. Margins covered with a few short hairs, central part glabrous.

THORACIC SHIELD. Surface like those of tergites, glabrous.

Tergites. Smooth and glabrous, no small pits. Paratergites projecting slightly posteriorly.

ENDOTERGUM. Inner section with numerous short spines and isolated bristles. Between marginal ridge and inner area a single row of sparse large, circular cuticular impressions, distance between impressions larger than their diameter. Marginal brim wavy towards inner area. Externally 1 or 2 rows of marginal bristles. Bristles scaly, of medium length, longest reaching slightly above tergite margin (Fig. 10A).

ANAL SHIELD. Rounded, neither bell-shaped nor tapered, covered with numerous short setae. Ventral side of anal shield with two black locking carinae, located close to laterotergites. Anterior carina small and posterior carina 3 times as long as anterior carina.

LEGS. Leg 1 with 1 ventral spine, leg 2 with 2-4, leg 3 with 3 or 4. First two leg pairs without an apical spine, spine present on leg 3. Leg pairs 4-21 with 7 or 8 ventral spines and an apical spine. On leg 9, femur 2.4 and tarsus 4.2 times as long as wide. All podomeres with setae (Fig. 11A).

\section{Male sexual characters}

GONOPORE. Covered with a single undivided, rounded, apically membranous, basally sclerotized plate, covering $1 / 4$ of surface of coxa. Gonopore located basally on joint (Fig. 11B).

ANTERIOR TELOPODS. Harp with two stridulation ribs, mesal rib smaller than lateral one, both ribs well developed, located in mesal corner (Fig. 11D). First podomere 1.1 times as wide as long. Second podomere process lobe-like and slightly curved, with rounded edges, protruding up to half of third podomere height, apically with sclerotized spots. Third podomere long, as long as first; cavity mesally with numerous sclerotized spots and three thin, sclerotized spines; one sclerotized spot located close to tip; laterally with up to 12 crenulated teeth. Podomeres 1-3 covered on both sides with numerous long, isolated hairs.

POSTERIOR TELOPODS. Movable finger with a well-rounded tip, tapering towards tip; hollowed-out inner margin without lobes but with 5 sclerotized spines, 2 located apically, 2 at midpoint and 1 basally (Fig. 11H). Posterior aspect of movable finger with ca 14 small sclerotized teeth (Fig. 11G). Movable finger slightly longer than fixed finger, the latter slender (4 times as long as wide), apically curved towards former. Fixed finger basally with a single spine, at margin with numerous sclerotized spots. First podomeres almost glabrous, movable and immovable finger covered on both sides with numerous long, isolated hairs, only tips of chela glabrous.

\section{Female}

Unknown.

\section{Distribution and ecology}

This species is currently known only from the vast lowland rainforests of the Masoala Peninsula on the east coast (Fig. 3).

\section{Remarks}

Despite several attempts, no DNA could be extracted from the male holotype. Therefore, its degree of similarity to the two much larger females known and sequenced from the Masoala area (KY399024 and KY399025) could not be assessed (see Fig. 1). 


\title{
Zoosphaerium piligerum species-group
}

\section{Remarks}

Species can be identified as members of the Z. piligerum species-group based on morphological characters of the posterior telopods (Wesener \& Wägele 2008), which are slender and greatly elongated. The species-group now contains four described species distributed in the eastern rainforests at higher elevations (Wesener 2009).

\section{Key to species of the Zoosphaerium piligerum species-group}

1. Antenna with four apical cones. Endotergum without cuticular impressions. Third podomere of anterior telopods lateral of cavity without sclerotized teeth. Body length $<20 \mathrm{~mm}$. Movable finger of posterior telopods $>4.5$ times as long as wide .........Z. micropiligerum Wesener, 2009

- Antenna with $>10$ apical cones. Endotergum with a single row of circular cuticular impressions. Third podomere of anterior telopods with at least two large, sclerotized teeth. Body length of mature females $>35 \mathrm{~mm}$. Movable finger of posterior telopods $\leq 3.5$ times as long as wide .......2

2. Anal shield bell-shaped. Posterior telopod fixed finger strongly curved, ca $25 \%$ shorter than movable finger. Operculum of vulva protruding above coxal margin. Endotergum with two rows of marginal bristles, slightly extending beyond tergite margin

Z. piligerum (de Saussure \& Zehntner, 1897)

- Anal shield well rounded. Posterior telopod fixed finger slightly curved, only slightly shorter than movable finger. Operculum of vulva not reaching coxal margin. Endotergum with a single row of marginal bristles, not reaching tergite margin

3. Tergites matte, covered with short setae, dark brown. Third podomere of anterior telopods laterally with 3 or 4 crenulated teeth. Legs with 10-12 ventral spines

Z. spinopiligerum sp. nov.

- Tergites glossy, black. Third podomere of anterior telopods laterally with 1 or 2 crenulated teeth. Legs with 8 or 9 ventral spines Z. pseudopiligerum Wesener, 2009

\author{
Zoosphaerium spinopiligerum sp. nov. \\ urn:1sid:zoobank.org:act:B5E6A6B0-F750-4227-8F0B-4F6417FDF88D
}

Figs $2 \mathrm{G}, 3,10 \mathrm{~B}, 12$

\section{Diagnosis}

The greatly elongated posterior telopods identify Zoosphaerium spinopiligerum sp. nov. as a member of the Z. piligerum species-group. Zoosphaerium spinopiligerum sp. nov. shares the shape of the vulva and the anal shield, as well as a similar posterior telopod with $Z$. pseudopiligerum. Zoosphaerium spinopiligerum sp. nov. differs from the latter in the non-glossy tergites, differences in the shape of the anterior telopods, as well as the higher number of ventral spines on the legs (see key above).

\section{Etymology}

'Spinopiligerum', noun in apposition, as a reference to the higher number of ventral spines on the legs compared to related species.

\section{Material examined}

Holotype

MADAGASCAR - Fianarantsoa • ${ }^{\lambda}$; Parc National de Midongy-Befotaka, $6 \mathrm{~km}$ N of Befotaka village; $23^{\circ} 46.7^{\prime} \mathrm{S}, 47^{\circ} 06.4^{\prime} \mathrm{E}$; alt. $815 \mathrm{~m}$; dense humid transitional lowland and montane forest; 8 Feb. 2008; V. Soarimalala leg.; coll. no. VS-1442; FMNH-INS 3119885. 


\section{Other material}

MADAGASCAR - Fianarantsoa - 1 क; Parc National de Midongy-Befotaka, $11.5 \mathrm{~km} \mathrm{SW}$ of Befotaka village; $23^{\circ} 53.3^{\prime} \mathrm{S}, 46^{\circ} 53.3^{\prime} \mathrm{E}$; alt. $1053 \mathrm{~m}$; dense humid transitional lowland and montane forest; 27 Feb. 2008; V. Soarimalala leg.; coll. no. VS-1536; FMNH-INS 3119888.

\section{Description}

Body LenGth. Male: length $37.1 \mathrm{~mm}$, width of thoracic shield $22.3 \mathrm{~mm}$ (widest), height of thoracic shield $11.1 \mathrm{~mm}$ (highest). Female (paratype): length $28.8 \mathrm{~mm}$, width of thoracic shield $16.8 \mathrm{~mm}$, height of thoracic shield up to $8.7 \mathrm{~mm}$.

Coloration. Tergites brown with dark brown posterior margin (Fig. 2G). Collum dark brown to green. Head dark green with yellow-brown markings. Anal shield brown. Antennae dark green, legs basally light brown, apically dark green.

HEAD. Eyes with more than 80 ommatidia. Antennae long and slender, protruding back to leg 3. Length of antennomeres $1=2=3=4=5<6$. A shallow groove present on antennomere 1 , disc with $22 / 18$ apical cones.

GNATHOCHILARIUM AND MANDIBLE. Not dissected.

Stigmatic PLATES. First stigmatic plate lobular, apex well rounded, very slightly curved towards coxa. Hairs most abundant on apical margin (Fig. 12C).

PLEURITES. First pleurite slightly extending posteriorly in a long, thin process.

Collum. Median part of collum glabrous.

THORACIC SHIELD. Surface similar to that of tergites.

Tergites. Paratergites slightly projecting posteriorly. Tergites covered with small pits and hairs.

ENDOTERGUM. Inner section with numerous short spines and isolated bristles. Between marginal ridge and inner area a single row of sparse large, elliptical cuticular impressions, distance between impressions 2-3 times as large as their diameter. Marginal brim wavy towards inner area. Externally with 1 row of sparse marginal bristles. Bristles scaly, short, the longest reaching $1 / 3$ of distance towards tergite margin (Fig. 10B).

ANAL SHIELD. Rounded, slightly flattened in male, covered with numerous short setae. Ventral side of anal shield with two black locking carinae, located close to laterotergites. Anterior carina small, posterior carina 6 or 7 times as long as anterior carina.

LEGS. Leg 1 with 5 ventral spines, leg 2 with 6, leg 3 with 8. First two leg pairs without an apical spine, spine present on leg 3. Leg pairs 4-21 with 10-12 ventral spines and an apical spine. On leg 9, femur 2.1 and tarsus 5.2 times as long as wide. All podomeres with setae (Fig. 12A).

\section{Male sexual characters}

GONOPORE. Covered with a single undivided, rounded, apically membranous, basally sclerotized plate, covering $1 / 4$ of surface of coxa. Gonopore located basally on joint (Fig. 12B).

ANTERIOR TELOPODS. Harp with two stridulation ribs, both ribs of same size and well developed, located in mesal corner (Fig. 12D). First podomere 1.3 times as wide as long. Second podomere process lobe- 


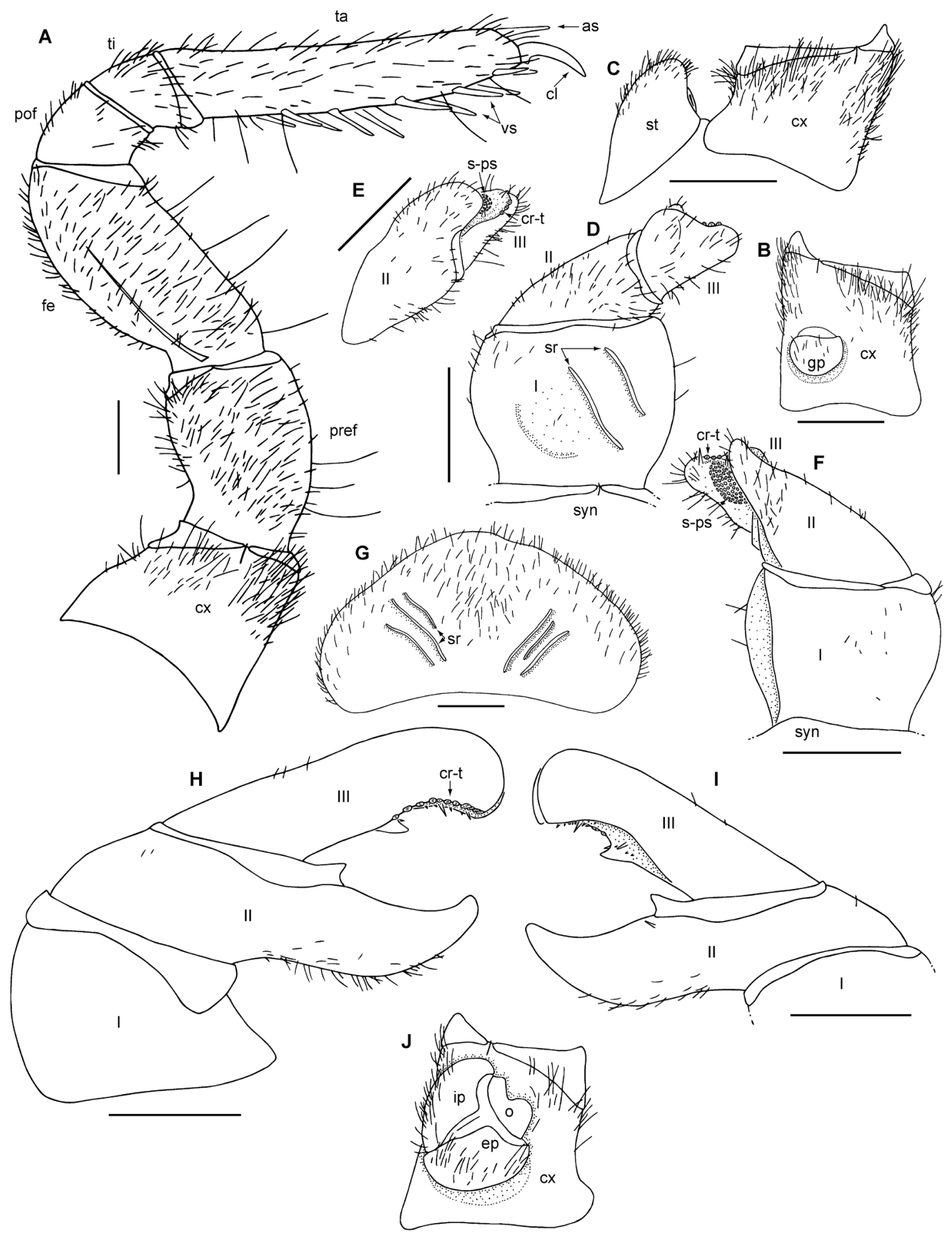

Fig. 12. Zoosphaerium spinopiligerum sp. nov., holotype (FMNH-INS 3119885). A. Right leg 9, posterior view. B. Left coxa 2 with gonopore, posterior view. C. Right coxa 1 with stigmatic plate, posterior view. D. Left anterior gonopod, anterior view. E. Left anterior gonopod, lateral view. F. Left anterior gonopod, posterior view. G. Female subanal plate with washboard. H. Right posterior telopod, posterior view. I. Right posterior telopod, anterior view. J. Left female coxa 2 with vulva, posterior view. Abbreviations: as = apical spine; $\mathrm{cl}=\mathrm{claw} ; \mathrm{cr}-\mathrm{t}=$ crenulated teeth; $\mathrm{cx}=\mathrm{coxa}$; $\mathrm{ep}=$ external plate; fe = femur; gp = gonopore; ip = inner plate; o = operculum; pof = postfemur; pref = prefemur; $\mathrm{s}-\mathrm{ps}=$ sclerotized spots; $\mathrm{sr}=$ stridulation rib; $\mathrm{st}=$ stigmatic plate; $\mathrm{syn}=$ syncoxite; $\mathrm{ta}=$ tarsus; $\mathrm{ti}=$ tibia; $\mathrm{vs}=$ ventral spines. Roman numerals indicate telopoditomeres. Scale bars $=1 \mathrm{~mm}$. 
like and slightly curved, with rounded edges, protruding up to $2 / 3$ of third podomere height, apically with sclerotized spots, visible in anterior view (Fig. 12D-F). Third podomere narrow, half as long as first; cavity mesally with numerous sclerotized spots and three thin, sclerotized spines (Fig. 12E-F); one sclerotized spot located close to tip; laterally with up to 4 crenulated teeth. Podomeres $1-3$ on both sides with numerous long, isolated hairs.

POSTERIOR TELOPODS (FIGS). Movable finger strongly curved, apically with invagination. Hollowed-out inner margin with one large triangular membranous lobe and 3-5 smaller sclerotized spines (Fig. 12H). Posterior aspect of movable finger with ca 11 small, sclerotized teeth (Fig. 12I). Immovable finger slender, with weakly curved tip, slightly shorter than movable finger. Anterior side of immovable finger basally with a membranous lobe and a sclerotized spine, at tip with numerous small sclerotized spots (Fig. 12I). All three podomeres of posterior telopods on both sides glabrous. Inner horns of syncoxite apically curved posteriorly. Tips sharp, entire horns covered with numerous short hairs.

\section{Female sexual characters}

Subanal plate wide, slightly triangular. Washboard with well-developed stridulation ribs, with 3 ribs on each half (Fig. 12G). Vulva large, covering more than $2 / 3$ of coxa (Fig. 12J). Operculum small and low, ending far before coxal margin. Apical margin of operculum medially notched, lateral tip twice as high as mesal one, well rounded. Mesal plate long, extending beyond operculum.

\section{Distribution and ecology}

Zoosphaerium spinopiligerum sp. nov. occurs in sympatry with Z. nigrum sp. nov. and Sphaeromimus midongy Moritz \& Wesener, 2017 in the remote mountainous forests of Midongy in the southeast of Madagascar (Fig. 3).

\section{Remarks}

The female specimen examined here is only tentatively placed in Z. spinopiligerum sp. nov. as its COI barcode shows quite a p-distance to the male holotype (Table 2). Such a distance is far higher than usually present in millipedes.

\section{New locality data for Zoosphaerium species in Madagascar}

\section{Zoosphaerium neptunus (Butler, 1872)}

Sphaerotherium digitale de Saussure \& Zehntner, 1897: pl. 5 fig. 16. Sphaerotherium pygidiale de Saussure \& Zehntner, 1902: 42.

See Wesener \& Wägele (2008) for a revision and Wesener (2016) for a complete bibliography.

\section{Material examined}

MADAGASCAR - Antsiranana • 3 $\widehat{\partial}$; SAVA, Parc National de Marojejy, $6.5 \mathrm{~km}$ NW of Manantenina village; $14^{\circ} 27^{\prime} 21.2^{\prime \prime} \mathrm{S}, 4^{\circ} 46^{\prime} 29.8^{\prime \prime} \mathrm{E}$; alt. $780 \mathrm{~m}$; disturbed lowland humid forest, pitfalls; 31 May 2016; V. Soarimalala leg.; FMNH-INS 2858681 • >30 juvs; Marojejy; $14^{\circ} 26^{\prime} \mathrm{S}, 49^{\circ} 45^{\prime}$ E; alt. $700 \mathrm{~m}$; 10-17 Nov. 1993; NHMD. - Toamasina • 1 क; Reserve Betampona, Camp Rendrirendry, $34.1 \mathrm{~km}$ $332^{\circ}$ from Toamasina; $17^{\circ} 55.26^{\prime \prime} \mathrm{S}, 049^{\circ} 11.59^{\prime \prime} \mathrm{E}$; alt. $390 \mathrm{~m}$; general collecting in camp, rainforest; 28 Nov. 2005; Brian L. Fisher et al. leg.; coll. no. BLF 13126; CASENT 9032818 • 1 q; Reserve Nationale Integrale Betampona, Betampona, $35.1 \mathrm{~km} \mathrm{NW}$ of Toamasina; 1755.05" S, 49 $12.03^{\prime \prime} \mathrm{E}$; alt. 500 m; rainforest, general collecting; 15-17 Dec. 2007; Brian L. Fisher et al. leg.; coll. no. BLF 19514; CASENT 9068298 • 1 क ; Region Atsinanana, Reserve Naturelle Integrale, along Piste Principale 
(PP); $17^{\circ} 54.8^{\prime} \mathrm{S}, 49^{\circ} 11.6^{\prime} \mathrm{E}$; alt. 400-500 m; in relatively intact lowland humid forest, pitfall 2, bucket 6; 10 Nov. 2015; Steven M. Goodman leg.; FMNH-INS SMG-19237 • 1 q; same collection data as for preceding; by hand; coll. no. SMG-19235; FMNH-INS 2858602 • 1 क ; same collection data as for preceding; pitfall 3, bucket 5; 11 Nov. 2015; coll. no. SMG-19246; FMNH-INS 2858597 • 1 ᄋ; same collection data as for preceding; coll. no. SMG-19247; FMNH-INS 2858600 • 1 ; same collection data as for preceding; pitfall 1; 12 Nov. 2015; coll. no. SMG-19255; FMNH-INS 2858599 • 1 q; same collection data as for preceding; pitfall 3; coll. no. SMG-19256; FMNH-INS 2858604 • 1 o'; same collection data as for preceding; pitfall 2; coll. no. SMG-19254; FMNH-INS 2858593 - 1 के; same collection data as for preceding; pitfall 1; 13 Nov. 2015; coll. no. SMG-19263; FMNH-INS 2858594 •

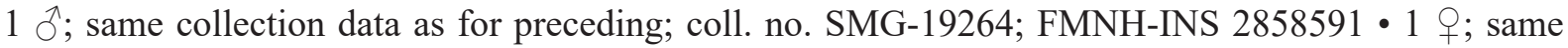
collection data as for preceding; pitfall 3; 15 Nov. 2015; coll. no. SMG-19271; FMNH-INS 2858603 • 1 \%; Region Atsinanana, Reserve Naturelle Integrale, along Piste Principale (PP) between 1650 and $2550 \mathrm{~m} ; 1^{\circ} 54.62^{\prime} \mathrm{S}, 49^{\circ} 11.70^{\prime} \mathrm{E}$; alt. 460-520 $\mathrm{m}$; in undisturbed lowland humid forest, pitfall 4, bucket 8; 17 Nov. 2015; Steven M. Goodman leg.; coll. no. SMG-19289; FMNH-INS 2858598 • 1 §’; same collection data as for preceding; bucket 11; coll. no. SMG-19291; FMNH-INS 2858590 • 1 ; ; same collection data as for preceding; pitfall 5, bucket 3; coll. no. SMG-19290; FMNH-INS 2858596 • 1 万; same collection data as for preceding; pitfall 4, bucket 1; 21 Nov. 2015; coll. no. SMG-19313; FMNHINS 2858592.

\section{Remarks}

We provide further locality information including the lowland forest of Betampona and lowland forests in Marojejy for this relatively widespread species of Zoosphaerium (Fig. 13A). The gigantic females of $Z$. neptunus are currently the largest Sphaerotheriida known, reaching the size of a tennis ball or small orange when rolled up. The juveniles of this species show swarming behavior around Andasibe (Wesener \& Schütte 2010), a so far unique behavior for giant pill-millipedes.

\section{Zoosphaerium platylabum (de Saussure \& Zehntner, 1897)}

See Wesener \& Wägele (2008) for a revision and Wesener (2016) for a complete bibliography.

\section{Material examined}

MADAGASCAR - Toamasina - 1 ô; Forêt d'Analamay, $9 \mathrm{~km}$ NE of Ambohimanarivo village; $18^{\circ} 47^{\prime} 55.4^{\prime \prime} \mathrm{S}, 48^{\circ} 19^{\prime} 23.6^{\prime \prime} \mathrm{E}$; alt. $1100 \mathrm{~m}$; degraded montane forest, pitfall buckets; 14 Jan. 2009; V. Soarimalala leg.; coll. no. VS-1635; FMNH-INS 3195652 • 1 đ̂̃; Foret d'Analamay, $10 \mathrm{~km}$ E of Ambohimanarivo village; $18^{\circ} 48^{\prime} 29.4^{\prime \prime} \mathrm{S}, 48^{\circ} 20^{\prime} 13.8^{\prime \prime} \mathrm{E}$; alt. $1060 \mathrm{~m}$; dense humid transitional lowland and montane forest; 31 Jan. 2009; V. Soarimalala leg.; FMNH-INS 3119883 - 1 ô; Parc National de Zahamena, Onibe River; $17^{\circ} 45^{\prime} 33^{\prime \prime} \mathrm{S}, 48^{\circ} 51^{\prime} 17^{\prime \prime} \mathrm{E}$; alt. $780 \mathrm{~m}$; rainforest, general collecting in camp; 21 Feb. 2009; B.L. Fisher et al. leg.; coll. no. BLF 22169; CASENT 9068304 • 1 ô, 1 o; Corridor

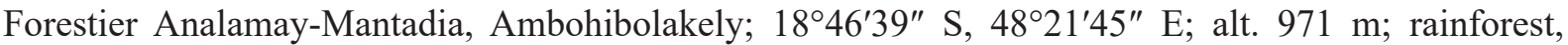
general collection; 23-28 Nov. 2012; B.L. Fisher et al. leg.; coll. no. BLF 29952; CASENT 9068293 • 2 specs; Alaotra-Mangoro, about $4.7 \mathrm{~km} \mathrm{NE}$ of Andasibe village; $18^{\circ} 54^{\prime} 4.2^{\prime \prime} \mathrm{S}, 48^{\circ} 27^{\prime} 00.0^{\prime \prime} \mathrm{E}$; alt. 985 m; degraded lower montane forest, pitfalls; Jan. 2014; Toky Randriamora leg.; FMNH-INS 2858672 • $1 \mathrm{~d}$; Alaotra-Mangoro, $1.5 \mathrm{~km} \mathrm{~N}$ of Sahavarina village, about $4.5 \mathrm{~km} \mathrm{NW}$ of Antaniditra village and $7 \mathrm{~km}$ SE of Ambatovy mine site; 18 $8^{\circ} 1^{\prime} 48.3^{\prime \prime} \mathrm{S}, 48^{\circ} 21^{\prime} 23.9^{\prime \prime} \mathrm{E}$; alt. $925 \mathrm{~m}$; open anthropogenic habitat and degraded lower montane forest, pitfalls; Mar. 2014; Toky Randriamora leg.; FMNH-INS 2858673 • 2 specs; same collection data as for preceding; coll. no. VS-1676; FMNH-INS $2858674 \bullet 1 \mathrm{spec}$.; same collection data as for preceding; FMNH-INS 3196509 - 1 spec.; Alaotra-Mangoro, about $1 \mathrm{~km} \mathrm{~S}$ of Ambodiriana village; $19^{\circ} 02^{\prime} 00.4^{\prime \prime} \mathrm{S}, 48^{\circ} 20^{\prime} 20.3^{\prime \prime} \mathrm{E}$; alt. $980 \mathrm{~m}$; degraded lower montane forest, pitfalls; Mar. 2014; Toky Randriamora leg.; FMNH-INS 2858675. 


\section{Remarks}

Zoosphaerium platylabum was previously known only from a few specimens collected near Andasibe (Wesener \& Wägele 2008; Wesener et al. 2010b). Now, the species has been found at several additional montane rainforest sites north of Andasibe, all at elevation levels of 780-1100 m (Fig. 13B).
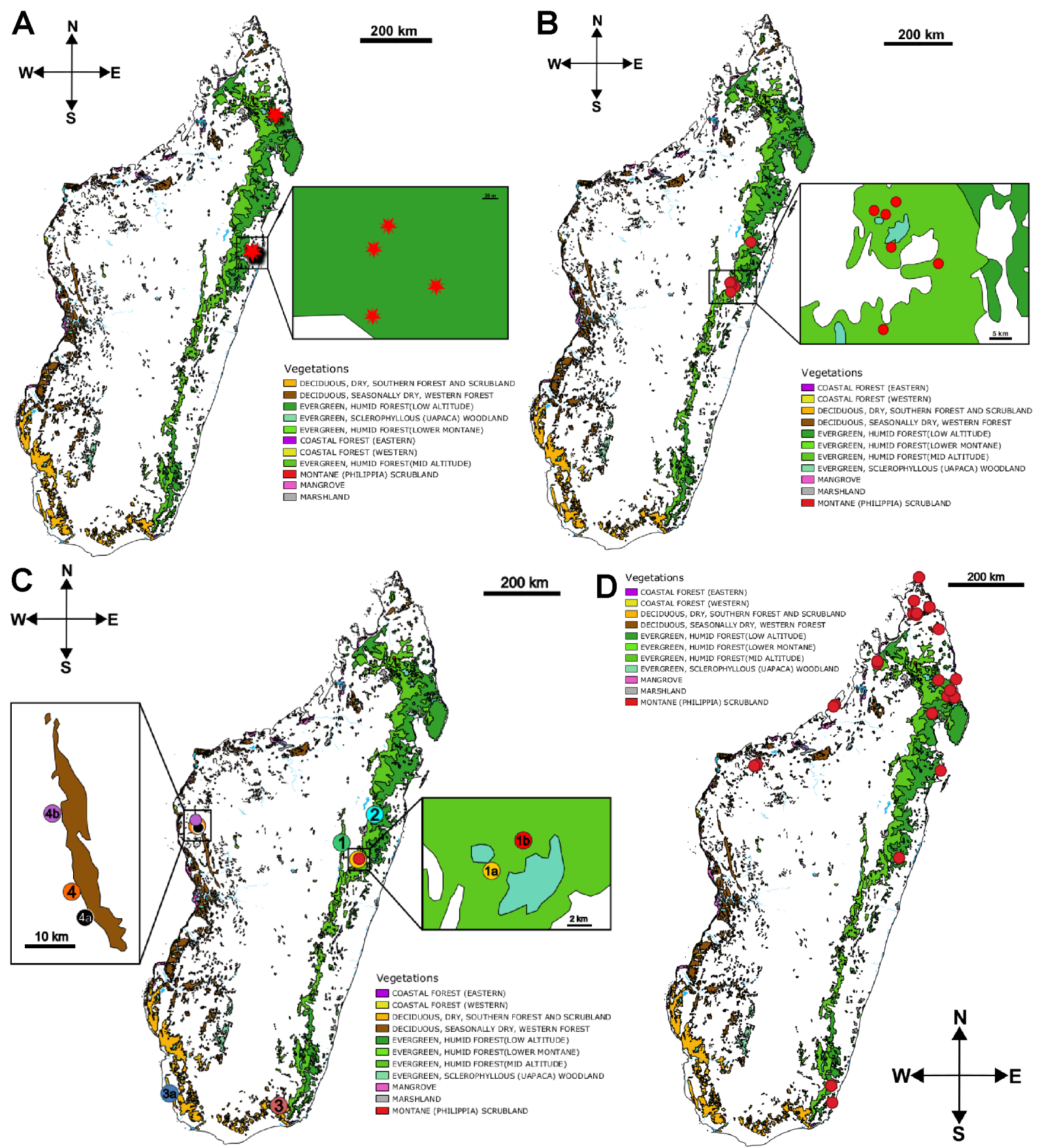

Fig. 13. Distribution maps marking new localities for known species of Zoosphaerium. Vegetation color marks modified from Moat \& Smith 2007. A. Z. neptunus (Butler, 1872). B. Z. platylabum (de Saussure \& Zehntner, 1897). C. $1=$ Z. piligerum (de Saussure \& Zehntner, 1897); $2=$ Z. villosum Wesener \& Sierwald, 2015; $3=$ Z. libidinosum (de Saussure \& Zehntner, 1897); $4=$ Zoosphaerium discolor Wesener, 2009. D. Unidentifiable juvenile Zoosphaerium samples. 
Zoosphaerium piligerum (de Saussure \& Zehntner, 1897)

See Wesener \& Wägele (2008) for a revision and Wesener (2016) for a complete bibliography.

\section{Material examined}

MADAGASCAR - Antananarivo • 1 spec.; Forêt d'Antsahabe, 6 km SE of Anjozorobe; $18^{\circ} 25.3^{\prime}$ S, 4756.6' E; alt. 1250 m; dense humid montane forest; 4 Dec. 2005; V. Soarimalala leg.; coll. no. VS-667; FMNH-INS 3119912. - Toamasina • 1 spec.; Forêt d'Analamay, $12.5 \mathrm{~km}$ E of Ambohimanarivo village; $18^{\circ} 48^{\prime} 20.8^{\prime \prime} \mathrm{S}, 48^{\circ} 21^{\prime} 38.1^{\prime \prime} \mathrm{E}$; alt. $1060 \mathrm{~m}$; dense humid transitional lowland and montane forest; 10 Feb.

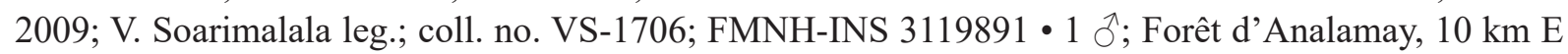
of Ambohimanarivo village; $18^{\circ} 49^{\prime} 25.9^{\prime \prime} \mathrm{S}, 48^{\circ} 20^{\prime} 1.8^{\prime \prime} \mathrm{E}$; alt. $1050 \mathrm{~m}$; dense humid transitional lowland and montane forest; 20 Feb. 2009; V. Soarimalala leg.; coll. no. VS-1741; FMNH-INS 3119882.

\section{Remarks}

Currently listed as critically endangered in the IUCN Red List (Rudolf \& Wesener 2017a), Z. piligerum seems to be more widespread in the eastern montane forests (Fig. 13C) than when the species was assessed as critically endangered in the IUCN Red List (Wesener \& Wägele 2008).

Zoosphaerium villosum Wesener \& Sierwald, 2005

\section{Material examined}

MADAGASCAR - Toamasina 1 o ; Parc National de Zahamena, Tetezambatana forest, near jct of Nosivola and Manakambahiny Rivers; $17^{\circ} 44^{\prime} 35^{\prime \prime}$ S, 48 43'46" E; alt. 860 m; general collecting in camp, rainforest; 18-19 Feb. 2009; B.L. Fisher et al. leg.; coll. no. BLF 21973; CASENT 9068292.

\section{Remarks}

Another locality for this species (Fig. 13C), which appears to be common in northeastern Malagasy lowland rainforests, is added (cf Wesener et al. 2010b).

\section{Zoosphaerium libidinosum (de Saussure \& Zehntner, 1897)}

See Wesener \& Wägele (2008) for a revision and Wesener (2016) for a complete bibliography.

\section{Material examined}

MADAGASCAR - Toliara $1{ }^{\lambda}$; Mahafaly Plateau, Atsimo-Anrefena, $4 \mathrm{~km}$ NE of Vohombe village; $24^{\circ} 23.9^{\prime} \mathrm{S}, 43^{\circ} 50.8^{\prime} \mathrm{E}$; alt. $80 \mathrm{~m}$; in spiny bush, pitfalls; 27 Feb. 2003; Voahangy Soarimalala leg.; coll. no. VS-540; FMNH-INS $3196503 \cdot 1$ spec.; $10.0 \mathrm{~km} \mathrm{SSW}$ of Tranomaro, along Vohondava River; $24^{\circ} 41.2^{\prime} \mathrm{S}, 46^{\circ} 27.2^{\prime} \mathrm{E}$; alt. $225 \mathrm{~m}$; spiny bush; 18 Mar. 2005; V. Soarimalala leg.; coll. no. VS-572; FMNH-INS 3177004.

\section{Remarks}

Additional locality data for this very widespread species, occurring almost everywhere in the southern spiny forest ecosystem, is provided (Fig. 13C).

\section{Zoosphaerium discolor Wesener, 2009}

\section{Material examined}

MADAGASCAR - Mahajanga • 1 क; Forêt de Beanka, $4.9 \mathrm{~km} \mathrm{~S}$ of Ambinda; $18^{\circ} 03.7^{\prime} \mathrm{S}, 44^{\circ} 31.5^{\prime} \mathrm{E}$; alt. $320 \mathrm{~m}$; slightly disturbed dry deciduous tsingy forest; 27 Oct. 2009; V. Soarimalala leg.; coll. no. VS-1783; FMNH-INS 3119880 • 1 q; Majunga, Reserve forestière Beanka, 50.7 km E of Maintirano; 
$17^{\circ} 52^{\prime} 49^{\prime \prime} \mathrm{S}, 44^{\circ} 28^{\prime} 08^{\prime \prime} \mathrm{E}$; alt. $140 \mathrm{~m}$; tropical dry forest on tsingy, general collecting; 28-31 Oct. 2009; B.L. Fisher et al. leg.; coll. no. BLF23002; CASENT9068288 • 1 गे; Forêt de Beanka; $18^{\circ} 01.25^{\prime}$ S, $44^{\circ} 30.08^{\prime} \mathrm{E}$; alt. $220 \mathrm{~m}$; slightly disturbed dry deciduous forest; 14 Jan. 2010; Z.H. Harimpiria leg.; FMNH-INS 3119897B.

\section{Remarks}

This species, previously known from the western dry forests of Bemaraha and Kirindy (Wesener 2009), has now also been recorded from Beanka (Fig. 13C).

Zoosphaerium aureum Wesener, 2009

\section{Material examined}

MADAGASCAR - Antsiranana • 1 ồ; Montagne d'Ambre; $12^{\circ} 32^{\prime}$ S, $49^{\circ} 10^{\prime}$ E; alt. 1100 m; 23-28 Nov. 1993; NHMD.

\section{Remarks}

We provide collection information for one additional specimen from the type locality. Zoosphaerium aureum is currently classified as Least Concern (Rudolf \& Wesener 2017b) on the IUCN Red List.

\section{Zoosphaerium smaragdinum Wesener, 2009}

\section{Material examined}

MADAGASCAR - Antsiranana • 3 juvs; Marojejy; 14²6' S, 4945’ E; alt. 700 m; 10-17 Nov. 1993; NHMD.

\section{Remarks}

Three more specimens have been collected from the type locality. Zoosphaerium smaragdinum is currently classified as Near Threatened (Rudolf \& Wesener 2017c) on the IUCN Red List.

\section{Zoosphaerium ambrense Wesener, 2009}

\section{Material examined}

MADAGASCAR - Antsiranana - 1 ; Montagne d'Ambre, $2 \mathrm{~km}$ away from park entrance; $12^{\circ} 32^{\prime}$ S, $49^{\circ} 10^{\prime}$ E; alt. 1000 m; 23-28 Nov. 1993; J. Coddington, N. Scharff, S. Larcher, C. Griswold and R. Andriamasimanana leg.; NHMD • $1 \hat{\jmath}, 2$ 우; same collection data as for preceding; alt. $1100 \mathrm{~m}$; NHMD $\bullet 1 \hat{\delta}$; same collection data as for preceding; NHMD $\bullet 1 \hat{\delta}$; same collection data as for preceding; NHMD $\bullet 1 \hat{\jmath}$; same collection data as for preceding; NHMD $\bullet 1 \hat{\jmath}$; same collection data as for preceding; NHMD.

\section{Remarks}

We provide collection information for several more specimens of $Z$. ambrense that were sampled at the type locality.

\section{Zoosphaerium corystoides Wesener, 2009}

\section{Material examined}

MADAGASCAR - Antsiranana - $2 \partial^{\lambda}, 2$ specs; Montagne d'Ambre; 12³2' S, 49¹0' E; alt. 1100 m; 23-28 Nov. 1993; J. Coddington, N. Scharff, S. Larcher, C. Griswold and R. Andriamasimanana leg.; NHMD • 1 ते; same collection data as for preceding; NHMD. 


\section{Remarks}

Additional specimens were collected at the type locality, Montagne d'Ambre. Zoosphaerium corystoides is currently classified as Least Concern (Rudolf \& Wesener 2017d) on the IUCN Red List.

Unidentifiable Zoosphaerium spp. (mainly immatures)

\section{Material examined}

MADAGASCAR - Antsiranana - 1 spec.; Marojejy Res.; 4 km NNW of Manantenina; $14^{\circ} 26^{\prime}$ S, 49 $45^{\prime}$ E; alt. 700 m; 10-16 Nov. 1993; J. Coddington, N. Scharff, S. Larcher, C. Griswold and R. Andriamasimanana leg.; NHMD • 1 क; Montagne d'Ambre; $12^{\circ} 32^{\prime} \mathrm{S}, 49^{\circ} 10^{\prime} \mathrm{E}$; alt. $1100 \mathrm{~m}$; 23-28 Nov. 1993; J. Coddington, N. Scharff, S. Larcher, C. Griswold and R. Andriamasimanana leg.; NHMD • 1 spec.; same collection data as for preceding; NHMD • 2 specs; N Ankarana Reserve, base of tsingy summit; $12.8461^{\circ} \mathrm{S}, 49.15^{\circ} \mathrm{E}$; alt. $284 \mathrm{~m}$; dry deciduous forest on limestone; 8 Apr. 2007; Ken Emberton leg.; coll. no. MBI-2038; FMNH-INS 000103908 • 1 spec.; N Ankarana Reserve, local tsingy, summit; $12.8465^{\circ} \mathrm{S}, 49.1503^{\circ} \mathrm{E}$; alt. $294 \mathrm{~m}$; dry deciduous forest on limestone; 8 Apr. 2007; Ken Emberton leg.; coll. no. MBI-2037; FMNH-INS 000103909 • 1 spec.; NE Ankarana Reserve, roadside; $12.8329^{\circ} \mathrm{S}$, 49.2286 ${ }^{\circ}$ E; alt. 331 m; dry deciduous forest on lava; 14 Apr. 2007; Ken Emberton leg.; coll. no. MBI2066; FMNH-INS $000103904 \cdot 2$ specs; E Ankarana Reserve, talus and rocks below $20 \mathrm{~m}$ tsingy cliff; $12.8609^{\circ} \mathrm{S}, 49.2267^{\circ} \mathrm{E}$; alt. $294 \mathrm{~m}$; dry deciduous forest on limestone; 14 Apr. 2007; Ken Emberton leg.; coll. no. MBI-2068; FMNH-INS 000103911 • 1 spec.; NE Ankarana Reserve, local limestone summit; $12.8738^{\circ} \mathrm{S}, 49.2249^{\circ} \mathrm{E}$; alt. $315 \mathrm{~m}$; dry deciduous forest on limestone; 14 Apr. 2007; Ken Emberton leg.; coll. no. MBI-2064; FMNH-INS $000103920 \bullet 4$ specs; NE Ankarana Reserve, talus below tsingy visible from road; $12.8617^{\circ} \mathrm{S}, 49.2266^{\circ} \mathrm{E}$; alt. $266 \mathrm{~m}$; dry deciduous forest on limestone; $14 \mathrm{Apr}$. 2007; Ken Emberton leg.; coll. no. MBI-2062; FMNH-INS 000103922 • 2 spec.; NE Analamerana, near summit; $12.6833^{\circ} \mathrm{S}, 49.5333^{\circ} \mathrm{E}$; alt. $36 \mathrm{~m}$; litter-loam pockets in limestone brocks, dry deciduous forest on limestone; 23 Apr. 2007; Ken Emberton leg.; coll. no. MBI-2072; FMNH-INS 000103929 • 3 specs; NE Analamerana, $160 \mathrm{~m}$ downslope E from summit; $12.6833^{\circ} \mathrm{S}, 49.5333^{\circ} \mathrm{E}$; limestone outcrop, dry deciduous forest on limestone; 25 Apr. 2007; Ken Emberton leg.; coll. no. MBI-2086; FMNH-INS 000103921 • 1 spec.; NE Analamerana, on W bank of Antafiamantsina River, at waterfall, $3^{\text {rd }}$ rapid up; $12.6833^{\circ} \mathrm{S}, 49.5333^{\circ} \mathrm{E}$; dry deciduous forest on limestone; 26 Apr. 2007; Ken Emberton leg.; coll. no. MBI-2099; FMNH-INS 000103903 • 7 specs; NE Analamerana, small tsingy $180 \mathrm{~m}$ above river, ca 30 minute walk; $12.6833^{\circ} \mathrm{S}, 49.5333^{\circ} \mathrm{E}$; dry deciduous forest on limestone; $26 \mathrm{Apr}$. 2007; Ken Emberton leg.; coll. no. MBI-2094; FMNH-INS 000103917 • 2 specs; N Cap d'Ambre, Pointe du Phoque; $11.9698^{\circ} \mathrm{S}, 49.2845^{\circ} \mathrm{E}$; alt. $11 \mathrm{~m}$; spring-bottle tree stand, dry deciduous forest on limestone; 4 May 2007; Ken Emberton leg.; coll. no. MBI-2108; FMNH-INS 000103910 • 2 specs; NW of Antalaha, S of Mahadera, Mt. Ambohodrapaka; $14.6805^{\circ} \mathrm{S}, 50.0325^{\circ} \mathrm{E}$; alt. $270 \mathrm{~m}$; partially cut rainforest on granite; 29 Jul. 2007; Ken Emberton leg.; coll. no. MBI-2403; FMNH-INS 000103906 • 2 specs; same collection data as for preceding; coll. no. MBI-2404; FMNH-INS $000103907 \bullet 1$ spec.; NW of Antalaha, S of Mahadera, Mt Ambohodrapaka; $14.6836^{\circ} \mathrm{S}, 50.031^{\circ} \mathrm{E}$; alt. $369 \mathrm{~m}$; partially cut rainforest on granite; 29 Jul. 2007; Ken Emberton leg.; coll. no. MBI-2417; FMNH-INS 000103924 • 1 spec.; NW of Antalaha; 14. $4123^{\circ} \mathrm{S}, 50.1755^{\circ}$ E; alt. 1790 m; 30 Jul. 2007; Ken Emberton leg.; coll. no. MBI-2439; FMNH-INS $000103905 \cdot 2$ specs; NW of Antalaha, S of Mahadera, Mt Ambohodrapaka; $14.6873^{\circ} \mathrm{S}, 50.0301^{\circ} \mathrm{E}$; alt. $499 \mathrm{~m}$; rainforest, on quartzite; $30 \mathrm{Jul} .2007$; Ken Emberton leg.; coll. no. MBI-2430; FMNH-INS 000103915 • 1 spec.; NW of Antalaha, S of Mahadera, Mt. Ambohodrapaka; $14.6872^{\circ} \mathrm{S}, 50.0293^{\circ}$ E; alt. 545 m; 30 Jul. 2007; Ken Emberton leg.; coll. no. MBI-2434; FMNHINS $000103918 \cdot 1$ spec.; NW of Antalaha, SW of Andranofotsy, Mt Ambodivohitra; $14.8157^{\circ} \mathrm{S}$, 49.9634 ${ }^{\circ}$ E; alt. 487 m; rainforest on quartzite; 10 Aug. 2007; Ken Emberton leg.; coll. no. MBI2459; FMNH-INS 000103913 • 2 specs; NW of Antalaha, SW of Andranofotsy, Mt Ambodivohitra; 
WESENER T. \& SAGORNY C., Seven new giant pill-millipedes from Madagascar

$14.8157^{\circ}$ S, $49.9634^{\circ}$ E; alt. 487 m; rainforest on quartzite; 10 Aug. 2007; Ken Emberton leg.; coll. no. MBI-2459; FMNH-INS 000103 919 • 2 specs; NW of Antalaha, SW of Andranofotsy, Mt Ambodivohitra; $14.8166^{\circ} \mathrm{S}, 49.9622^{\circ} \mathrm{E}$; alt. $575 \mathrm{~m}$; rainforest, pandanus, palms, sphagnum on quartzite; 11 Aug. 2007; Ken Emberton leg.; coll. no. MBI-2472; FMNH-INS 000103912 • 1 spec.; NW of Antalaha, $\mathrm{S}$ of Antsahanoro, riverside hill rainforest; $14.8434^{\circ} \mathrm{S}, 50.1372^{\circ} \mathrm{E}$; alt. $82 \mathrm{~m}$; on quartzite; 15 Aug. 2007; Ken Emberton leg.; coll. no. MBI-2498; FMNH-INS 000103916 • 1 spec.; NW of Antalaha, $\mathrm{S}$ of Antsahanoro; $14.8445^{\circ} \mathrm{S}, 50.1359^{\circ} \mathrm{E}$; alt. $131 \mathrm{~m}$; riverside hill rainforest on quartzite; 15 Aug. 2007; Ken Emberton leg.; coll. no. MBI-2512; FMNH-INS 000103934 • 2 specs; Mt Bobanora, about $40 \mathrm{~km} \mathrm{~W}$ of Vohemar; $13.2141^{\circ} \mathrm{S}, 49.7574^{\circ} \mathrm{E}$; alt. $320 \mathrm{~m}$; viny rainforest on basalt talus; $26 \mathrm{Aug}$. 2007; Ken Emberton leg.; coll. no. MBI-2550; FMNH-INS 000103914 • 1 spec.; Manongorivo Reserve, slope high above Berato; $14.0366^{\circ} \mathrm{S}, 48.2882^{\circ} \mathrm{E}$; alt. $897 \mathrm{~m}$; rainforest on metamorphic boulders; 17 Oct. 2007; Ken Emberton leg.; coll. no. MBI-2611; FMNH-INS 000103933 • 2 specs; Manongorivo Reserve, Monongorivo River junction with small tributary; $13.9846^{\circ} \mathrm{S}, 48.2891^{\circ} \mathrm{E}$; alt. $321 \mathrm{~m}$; rainforest on granite; 20 Oct. 2007; Ken Emberton leg.; coll. no. MBI-2619; FMNH-INS 000103941 • 5 specs; Manongorivo Reserve, riverside flat area below cliffs, Monongorivo River; $13.9818^{\circ} \mathrm{S}$, $48.2858^{\circ}$ E; alt. $281 \mathrm{~m}$; rainforest on granite; 20 Oct. 2007; Ken Emberton leg.; coll. no. MBI-2620; FMNH-INS 000103 943. - Mahajanga • 1 spec.; Namoroka Reserve, southern valley on NE side of tsingy; $16.469^{\circ} \mathrm{S}, 45.3647^{\circ} \mathrm{E}$; alt. $142 \mathrm{~m}$; dry deciduous forest on limestone; $25 \mathrm{Sep} .2007$; Ken Emberton leg.; coll. no. MBI-2567; FMNH-INS 000103936 • 2 specs; Namoroka Reserve, southern isolated tsingy canyon; $16.4674^{\circ} \mathrm{S}, 45.3806^{\circ} \mathrm{E}$; alt. 432 feet; dry deciduous forest on limestone; $27 \mathrm{Sep}$. 2007; Ken Emberton leg.; coll. no. MBI-2574; FMNH-INS 000103928 • 2 specs; Namaroka Reserve, southern isolated tsingy; $16.4871^{\circ} \mathrm{S}, 45.3371^{\circ} \mathrm{E}$; alt. $435 \mathrm{~m}$; dry deciduous forest on limestone; $27 \mathrm{Sep}$. 2007; Ken Emberton leg.; coll. no. MBI-2572; FMNH-INS 000103927 • 9 spec.; S Namaroka National Park, low tsingy baobobs; $16.4565^{\circ} \mathrm{S}, 45.4011^{\circ} \mathrm{E}$; alt. $115 \mathrm{~m}$; dry deciduous forest on limestone; 29 Sep. 2007; Ken Emberton leg.; coll. no. MBI-2578; FMNH-INS 000103923 • 1 spec.; Anjajavy, isolated steep limestone hill near Antsangabe; $15.0643^{\circ} \mathrm{S}, 47.2373^{\circ} \mathrm{E}$; alt. $30 \mathrm{~m}$; dry deciduous forest on limestone; 8 Oct. 2007; Ken Emberton leg.; coll. no. MBI-2592; FMNH-INS $000104000 \bullet 1$ spec.; Anjajavi, side of long tsingy hill near dry mudflat; $15.026^{\circ} \mathrm{S}, 47.2712^{\circ} \mathrm{E}$; alt. $22 \mathrm{~m}$; dry deciduous forest on limestone; 11 Oct. 2007; Ken Emberton leg.; coll. no. MBI-2595; FMNH-INS 000103940. - Toamasina 11 spec.; Andriantanely Massif; $18.6907^{\circ} \mathrm{S}, 48.8063^{\circ} \mathrm{E}$; alt. $589 \mathrm{~m}$; rainforest; 19 May 2008; Ken Emberton leg.; coll. no. MBI-2665; FMNH-INS 000103932 • 1 spec.; Andriantantely Massif, streamside cliff base; $18.6997^{\circ} \mathrm{S}, 48.806^{\circ} \mathrm{E}$; alt. $301 \mathrm{~m}$; in rainforest, on granite; 22 May 2008; Ken Emberton leg.; coll. no. MBI-2693; FMNH-INS 000103930 • 1 spec.; Makira Reserve, W of Andaparaty; $15.2302^{\circ} \mathrm{S}, 49.5975^{\circ}$ E; alt. 430 m; rainforest; 23 Nov. 2008; Ken Emberton leg.; coll. no. MBI-3152; FMNH-INS $000103939 \bullet 2$ specs; $\mathrm{N}$ of Manona littoral forest; $16.6028^{\circ} \mathrm{S}, 49.8037^{\circ} \mathrm{E}$; alt. 23 m; 2 Dec. 2008; Ken Emberton leg.; coll. no. MBI-3158; FMNH-INS 000103 937. - Toliara • 2 specs; W of Ehasity; $24.154^{\circ}$ S, $47.1821^{\circ} \mathrm{E}$; alt. 347 m; rainforest; 18 Aug. 2008; Ken Emberton leg.; coll. no. MBI-2966; FMNH-INS 000103938 • 1 spec.; Mount Ivohibe; $24.5607^{\circ} \mathrm{S}, 47.2065^{\circ} \mathrm{E}$; alt. 457 m; rainforest; 31 Aug. 2008; Ken Emberton leg.; coll. no. MBI-2900; FMNH-INS 000103931 • 1 spec.; W of Ehasity rainforest; $24.1514^{\circ}$ S, $47.178^{\circ}$ E; alt. 479 m; 18 Sep. 2008; Ken Emberton leg.; coll. no. MBI-2964; FMNH-INS 000103942.

Microsphaerotherium anjozorobe Wesener, 2009

\section{Material examined}

MADAGASCAR - Antananarivo - 1 ; Analamanga, $6.7 \mathrm{~km}$ SE of Anjozorobe village, Andasin'i Jaonera; $18^{\circ} 25.3^{\prime} \mathrm{S}, 47^{\circ} 56.6^{\prime} \mathrm{E}$; alt. $1250 \mathrm{~m}$; in disturbed montane forest, pitfalls 1-3; 19-23 Feb. 2016; Steven M. Goodman leg.; FMNH-INS 2858679. 


\section{Remarks}

This is another record of this rare miniaturized species (Wesener 2009), previously known only from the type series collected near Andranomay. This species is currently classified as Critically Endangered (Rudolf \& Wesener 2017e) on the IUCN Red List.

\section{Discussion}

\section{Interspecific distances}

The lowest interspecific distances of the COI barcoding gene in the genus Zoosphaerium were observed between Z. beanka sp. nov. and an unidentified female from Anjiamangirina with 8.6\% (Table 2). Generally, interspecific distances vary between 9.1 and 20\% in the genus Zoosphaerium. However, this genus remains poorly represented by genetic data, with only 15 of the 77 species being genetically sampled. In contrast to this, sequence data for the Malagasy giant pill-millipede genus Sphaeromimus is available for 11 of the 12 known species. In Sphaeromimus, whose species have a distribution restricted to southern Madagascar, interspecific distances vary between 8.3 and $20.8 \%$, with a single outlier at $5.4 \%$ (Wesener et al. 2014; Moritz \& Wesener 2017), the same range that is observed in Zoosphaerium. While intraspecific distances are generally below $2.5 \%$ in our dataset, at most three sequences are available for a single species. Unidentifiable females show genetic distances between 4.3 and $8.6 \%$ from identifiable male specimens, but any meaningful discussion of these specimens is difficult without the availability of male specimens and the inclusion of nuclear markers in future studies. Low intraspecific distances are also visible in the maximum likelihood tree, where species represented by more than one specimen are well-supported. This shows the usefulness of COI barcoding as a basis for species identification. However, the poor resolution within the genus Zoosphaerium and its non-monophyly provide clear evidence that the mitochondrial COI gene - containing little resolution at deeper evolutionary splits does not allow a reconstruction of the phylogeny.

\section{Giant pill-millipede diversity and endemism in Madagascar}

Most of the known species of Zoosphaerium are highly endemic to small scattered areas in Madagascar, which are rarely visited by scientists collecting soil arthropods, so that occurrence data is still sparse for many species. Numerous species in Madagascar, including giant pill-millipedes, are severely threatened by habitat fragmentation and destruction (Harper et al. 2007). As of today, 19 of 70 assessed giant pill-millipede species from Madagascar are in one of the top three categories of the IUCN Red List (e.g., Rudolf \& Wesener 2017a, 2017b, 2017c, 2017d). Therefore, further locality data for all species in this group is greatly needed in order to protect them. Although giant pill-millipedes have adapted to different ecosystems, several species show a striking microendemism. This microendemism is especially prevalent in rainforest and montane rainforest ecosystems of the island, with samples from forests never studied before often yielding undescribed species. In contrast to humid forests, species of Zoosphaerium from the spiny and western dry forest ecosystems appear to be more widespread, something that is not known for other millipede groups such as Spirobolida (Wesener et al. 2009a; Wesener 2020a, 2020b).

\section{Acknowledgements}

We are grateful for the help of Claudia Etzbauer with the barcoding, and for Karin Ulmens' help and advice at the SEM. Thorsten Klug produced the habitus photographs. Pooja A. Anilkumar created the maps and formatted the references. A study of the millipedes of Madagascar would have been impossible without the collection efforts of Brian L. Fisher and his team (CAS), as well as Steve Goodman and Voahangy Soarimalala (FMNH), for which we are deeply thankful. Our thanks go to Darrel Ubick (CAS), and to Crystal Maier and Petra Sierwald (FMNH) for arranging the loan of numerous specimens. Henrik Enghoff loaned out several specimens from the NHMD. Many thanks to the editor, Nesrine Akkari, and two anonymous reviewers for improving previous versions of this manuscript. 


\section{References}

Ali J.R. \& Aitchison J.C. 2008. Gondwana to Asia: plate tectonics, paleogeography and the biological connectivity of the Indian sub-continent from the Middle Jurassic through latest Eocene (166-35 Ma). Earth-Science Reviews 88 (3): 145-166.

Altschul S.F., Madden T.L., Schäffner A.A., Zhang J., Zhang Z., Miller W. \& Lipman D.J. 1997. Gapped BLAST and PSIBLAST: a new generation of protein database search programs. Nucleic Acids Research 25 (17): 3389-3402. https://doi.org/10.1093/nar/25.17.3389

Brolemann H.W. 1922. Liste des myriapodes de l'Academie Malagache de Tananarive. Bulletin de la Société zoologique de France 47: 223-278. https://doi.org/10.5962/bhl.part.3470

Chamberlin R.V. 1921. New Chilopoda and Diplopoda from the East Indian region. Annals and Magazine of Natural History, Series 97 (37): 50-87. https://doi.org/10.1080/00222932108632489

Enghoff H. 2003. Diplopoda, Millipedes. In: S.G. Goodman \& J.P. Benstead (eds) The Natural History of Madagascar: 617-627. The University of Chicago Press, Chicago.

Goodman S.M. \& Benstead J.P. 2005. Updated estimates of biotic diversity and endemism for Madagascar. Oryx 39 (1): 73-77. https://doi.org/10.1017/S0030605305000128

Hall T.A. 1999. BioEdit: a user-friendly biological sequence alignment editor and analysis program for Windows 95/98/NT. Nucleic Acids Symposium Series 41: 95-98.

Harper G.J., Steininger M.K., Tucker C.J, Juhn D. \& Hawkins F. 2007. Fifty years of deforestation and forest fragmentation in Madagascar. Environmental Conservation 34 (4): 325-333.

Hebert PD., Cywinska A., Ball S.L. \& Dewaard J.R. 2003. Biological identifications through DNA barcodes. Proceedings of the Royal Society of London B 270 (1512): 313-321.

https://doi.org/10.1098/rspb.2002.2218

Krause D.W. 2003. Late Cretaceous vertebrates of Madagascar: a window into Gondwanan biogeography at the end of the age of dinosaurs. In: Goodman S.M. \& Benstead J.P. (eds) The Natural History of Madagascar: 40-47. The University of Chicago Press, Chicago.

Moat J. \& Smith P. 2007. Atlas of the Vegetation of Madagascar Vegetation/Atlas de la Vegetation de Madagascar. Royal Botanic Gardens, Kew (bilingual edition).

Moritz L. \& Wesener T. 2017. Integrative description of two new species of Malagasy chirping giant pillmillipedes, genus Sphaeromimus (Diplopoda, Sphaerotheriida, Arthrosphaeridae). European Journal of Taxonomy 381: 1-25. https://doi.org/10.5852/ejt.2017.381

Myers N., Mittermeier R.A., Mittermeier C.G., Da Fonseca G.A. \& Kent J. 2000. Biodiversity hotspots for conservation priorities. Nature 403 (6772): 853-858. https://doi.org/10.1038/35002501

Pocock R.I. 1895. Description of new genera of Zephronidae, with brief preliminary diagnoses of some new species. Annals and Magazine of Natural History, Series 616 (95): 409-415.

https://doi.org/10.1080/00222939508680293

Rakotondrasoa L.O., Malaisse F. \& Bogaert J. 2017. Modélisation de la dynamique du paysage forestier de la Réserve Spéciale d'Ambatovaky (Nord-Est de Madagascar). Tropicultura 35 (4): 312-324.

Rudolf E. \& Wesener T. 2017a. Zoosphaerium piligerum. The IUCN Red List of Threatened Species 2017: e.T65525146A65527960. Available from

https://doi.org/10.2305/IUCN.UK.2017-1.RLTS.T65525146A65527960.en [accessed 7 Apr. 2020]. 
Rudolf E. \& Wesener T. 2017b. Zoosphaerium aureum. The IUCN Red List of Threatened Species 2017: e.T65524362A65527855. Available from https://doi.org/10.2305/IUCN.UK.2017-1.RLTS.T65524362A65527855.en [accessed 7 Apr. 2020].

Rudolf E. \& Wesener T. 2017c. Zoosphaerium smaragdinum. The IUCN Red List of Threatened Species 2017: e.T65525770A65528000. Available from https://doi.org/10.2305/IUCN.UK.2017-1.RLTS.T65525770A65528000.en [accessed 7 Apr. 2020].

Rudolf E. \& Wesener T. 2017d. Zoosphaerium corystoides. The IUCN Red List of Threatened Species 2017: e.T65524417A65527885. Available from https://doi.org/10.2305/IUCN.UK.2017-1.RLTS.T65524417A65527885.en [accessed 7 Apr. 2020].

Rudolf E. \& Wesener T. 2017e. Microsphaerotherium anjozorobe. The IUCN Red List of Threatened Species 2017: e.T65524228A65527805. Available from https://doi.org/10.2305/IUCN.UK.2017-1.RLTS.T65524228A65527805.en [accessed 7 Apr. 2020].

Sagorny C. \& Wesener T. 2017. Two new giant pill-millipede species of the genus Zoosphaerium endemic to the Bemanevika area in northern Madagascar (Diplopoda, Sphaerotheriida, Arthrosphaeridae). Zootaxa 4263 (2): 273-294. https://doi.org/10.11646/zootaxa.4263.2.4

Saussure H. de \& Zehntner L. 1897. Atlas de l'histoire naturelle des Myriapodes. Histoire physique, naturelle et politique de Madagascar 27 (53): 1-12.

Saussure H. de \& Zehntner L. 1902. Myriapodes de Madagascar. In: Grandidier A. (ed.) Histoire physique, naturelle et politique de Madagascar 27 (53): i-viii,1-356.

Tamura K., Stecher G., Peterson D., Filipski A. \& Kumar S. 2013. MEGA6: Molecular Evolutionary Genetics Analysis version 6.0. Molecular Biology and Evolution 30 (12): 2725-2729.

https://doi.org/10.1093/molbev/mst197

Tavaré S. 1986. Some probabilistic and statistical problems in the analysis of DNA sequences. Lectures on Mathematics in the Life Sciences 17 (2): 57-86.

Trifinopoulos J., Nguyen L.T., von Haeseler A. \& Minh B.Q. 2016. W-IQ-TREE: a fast online phylogenetic tool for maximum likelihood analysis. Nucleic Acids Research 44 (W1): W232-W235. https://doi.org/10.1093/nar/gkw256

Wesener T. 2009. Unexplored richness: discovery of 31 new species of giant pill-millipedes endemic to Madagascar, with a special emphasis on micro-endemism (Diplopoda, Sphaerotheriida). Zootaxa 2097 (1): 1-131. https://doi.org/10.11646/zootaxa.2097.1.1

Wesener T. 2011. Re-discovery after more than a century: a redefinition of the Malagasy endemic millipede genus Zehntnerobolus, with a description of a new species (Diplopoda, Spirobolida, Pachybolidae). Zootaxa 3018 (1): 21-26. https://doi.org/10.11646/zootaxa.3018.1.3

Wesener T. 2014. A new phylogenetic analysis of the Sphaerotheriida (Diplopoda) with a revision of the Australian giant pill millipedes. Invertebrate Systematics 28 (2): 196-213.

https://doi.org/10.1071/IS13048

Wesener T. 2016. The giant pill-millipedes, order Sphaerotheriida - an annotated species catalogue with morphological atlas and list of apomorphies (Arthropoda: Diplopoda). Bonn Zoological BulletinSupplementum 63: 1-104.

Wesener T. 2020a. Ecotone shifts in southern Madagascar: first barcoding data and six new species of the endemic millipede genus Riotintobolus (Spirobolida, Pachybolidae). Zookeys 953: 1-29.

https://doi.org/10.3897/zookeys.953.53977 
Wesener T. 2020b. Dichromatobolus, a new genus of spirobolidan millipedes from Madagascar (Spirobolida, Pachybolidae). European Journal of Taxonomy 720: 107-120.

https://doi.org/10.5852/ejt.2020.720.1119

Wesener T. \& Anilkumar P.A. 2020. The millipedes collected by the Museum "La Specola" on Madagascar 1989/1991, with the description of three new species of giant pill-millipedes (Diplopoda, Sphaerotheriida, Arthrosphaeridae). In: Korsós Z. \& Dányi L. (eds) Proceedings of the $18^{\text {th }}$ International Congress of Myriapodology, Budapest, Hungary. ZooKeys 930: 3-35. https://doi.org/10.3897/zookeys.930.47620

Wesener T. \& Enghoff H. 2009. Revision of the millipede subfamily Spiromiminae, a Malagasy group with Indian connections? (Diplopoda Spirobolida Pachybolidae). Tropical Zoology 22 (1): 71-120.

Wesener T. \& Schütte K. 2010. Swarming behaviour and mass occurrences in the world's largest giant pill-millipede species, Zoosphaerium neptunus, on Madagascar and its implication for conservation efforts (Diplopoda: Sphaerotheriida). Madagascar Conservation and Development 5 (2): 89-94.

Wesener T. \& Sierwald P. 2005a. The giant pill-millipedes of Madagascar: revision of the genus Sphaeromimus, with a review of the morphological terminology (Diplopoda, Sphaerotheriida, Sphaerotheriidae). Proceedings of the California Academy of Sciences, Fourth Series 56 (29): 557-599.

Wesener T. \& Sierwald P. 2005b. New giant pill-millipede species from the littoral forest of Madagascar (Diplopoda, Sphaerotheriida, Zoosphaerium). Zootaxa 1097 (1): 1-60.

https://doi.org/10.11646/zootaxa.1097.1.1

Wesener T. \& vandenSpiegel D. 2009. A first phylogenetic analysis of giant pill-millipedes (Diplopoda: Sphaerotheriida), a new model Gondwanan taxon, with special emphasis on island gigantism. Cladistics 25 (6): 545-573. https://doi.org/10.1111/j.1096-0031.2009.00267.x

Wesener T. \& Wägele J.W. 2008. The giant pill-millipedes of Madagascar: revision of the genus Zoosphaerium (Myriapoda, Diplopoda, Sphaerotheriida). Zoosystema 30 (1): 5-82.

Wesener T., Enghoff H. \& Wägele J.W. 2008. Pachybolini - a tribe of giant Afrotropical millipedes: arguments for monophyly and the description of a new genus from Madagascar (Diplopoda: Spirobolida: Pachybolidae). Invertebrate Systematics 22: 37-53. https://doi.org/10.1071/IS07008

Wesener T., Enghoff H., Hoffman R.L., Wägele J.-W. \& Sierwald P. 2009a. Revision of the endemic giant fire millipedes of Madagascar, genus Aphistogoniulus (Diplopoda, Spirobolida, Pachybolidae). International Journal of Myriapodology 3: 15-52. https://doi.org/10.1163/187525409X462403

Wesener T., Enghoff H. \& Sierwald P. 2009b. Review of the Spirobolida on Madagascar, with descriptions of twelve new genera, including three genera of 'fire millipedes' (Diplopoda). ZooKeys 19: 1-128. https://doi.org/10.3897/zookeys.19.221

Wesener T., Raupach M.J. \& Sierwald P. 2010a. The origins of the giant pill-millipedes from Madagascar (Diplopoda: Sphaerotheriida: Arthrosphaeridae). Molecular Phylogenetics and Evolution 57 (3): 11841193. https://doi.org/10.1016/j.ympev.2010.08.023

Wesener T., Bespalova I. \& Sierwald P. 2010b. Madagascar's living giants: discovery of five new species of endemic giant pill-millipedes from Madagascar (Diplopoda: Sphaerotheriida: Arthrosphaeridae: Zoosphaerium). African Invertebrates 51 (1): 133-161.

Wesener T., Raupach M.J. \& Decker P. 2011a. Mountain refugia play a role in soil arthropod speciation on Madagascar: a case study of the endemic giant fire-millipede genus Aphistogoniulus. PLoS One 6 (12): e28035. https://doi.org/10.1371/journal.pone.0028035 
Wesener T., Köhler J., Fuchs S. \& vandenSpiegel D. 2011b. How to uncoil your partner - "mating songs" in giant pill-millipedes (Diplopoda: Sphaerotheriida). Naturwissenschaften 98 (11): 967-975. https://doi.org/10.1007/s00114-011-0850-8

Wesener T., Minh-Tu Le D. \& Loria S.F. 2014. Integrative revision of the giant pill-millipede genus Sphaeromimus, with the description of seven new species(Diplopoda, Sphaerotheriida, Arthrosphaeridae). ZooKeys 414: 67-104. https://doi.org/10.3897/zookeys.414.7730

Manuscript received: 3 December 2020

Manuscript accepted: 12 April 2021

Published on: 6 July 2021

Topic editor: Nesrine Akkari

Desk editor: Danny Eibye-Jacobsen

Printed versions of all papers are also deposited in the libraries of the institutes that are members of the EJT consortium: Muséum national d'histoire naturelle, Paris, France; Meise Botanic Garden, Belgium; Royal Museum for Central Africa, Tervuren, Belgium; Royal Belgian Institute of Natural Sciences, Brussels, Belgium; Natural History Museum of Denmark, Copenhagen, Denmark; Naturalis Biodiversity Center, Leiden, the Netherlands; Museo Nacional de Ciencias Naturales-CSIC, Madrid, Spain; Real Jardín Botánico de Madrid CSIC, Spain; Zoological Research Museum Alexander Koenig, Bonn, Germany; National Museum, Prague, Czech Republic. 